\title{
Thorium speciation in seawater
}

\author{
P.H. Santschi ${ }^{\text {a,* }}$, J.W. Murray ${ }^{\text {b }}$, M. Baskaran ${ }^{\text {c }}$, C.R. Benitez-Nelson ${ }^{\text {d }}$, L.D. Guo ${ }^{\text {e,1 }}$, \\ C.-C. Hung ${ }^{f, 2}$, C. Lamborg ${ }^{g}$, S.B. Moran ${ }^{h}$, U. Passow ${ }^{i}$, M. Roy-Barman ${ }^{j}$ \\ a Departments of Oceanography and Marine Sciences, Laboratory for Oceanographic and Environmental Research (LOER), \\ Texas A\&M University, 5007 Ave U, Galveston, TX 77551, United States \\ b School of Oceanography, Box 355351, University of Washington, Seattle, WA 98195-5351, United States \\ ${ }^{\mathrm{c}}$ Department of Geology, Wayne State University, Detroit, MI 48202, United States \\ d Department of Geological Sciences and Marine Science Program, University of South Carolina, Columbia, SC 29208, United States \\ e International Arctic Research Center, University of Alaska Fairbanks, 930 Koyukuk Drive, Fairbanks, AK 99775, United States \\ ${ }^{\mathrm{f}}$ Texas A\&M University, Department of Marine Sciences, Laboratory for Oceanographic and Environmental Research (LOER), \\ 5007 Ave U, Galveston, TX 77551, United States \\ ${ }^{g}$ Department of Marine Chemistry and Geochemistry, Woods Hole Oceanographic Institution, Woods Hole, MA 02543, United States \\ ${ }^{\mathrm{h}}$ Graduate School of Oceanography, University of Rhode Island, Narragansettt, RI 02882, United States \\ i Alfred-Wegener Institute for Marine and Polar Research, Am Handelshafen 12, D-27515 Bremerhaven, Germany \\ ${ }^{\mathrm{j}}$ LSCE, Domaine du CNRS, Bât 12-avenue de la Terrasse, F-91198 Gif-sur-Yvette Cedex, France
}

Received 19 February 2005; accepted 10 October 2005

Available online 7 February 2006

\begin{abstract}
Since the 1960s, thorium isotopes occupy a special place in the oceanographer's toolbox as tracers for determining rates and mechanisms of oceanic scavenging, particle dynamics, and carbon fluxes. Due to their unique and constant production rates from soluble parent nuclides of uranium and radium, their disequilibrium can be used to calculate rates and time scales of sinking particles. In addition, by ratio-ing particulate ${ }^{234} \mathrm{Th}$ (as well, in principle, other Th-nuclides) to carbon (and other elements), and linking this ratio to the parent-daughter disequilibrium in the water column, it is possible to calculate fluxes of carbon and other elements. Most of these applications are possible with little knowledge of the dissolved chemical properties of thorium, other than its oxidation state (IV) and tendency to strongly sorb to surfaces, i.e., its "particle- or surface-activity". However, the use of any tracer is hindered by a lack of knowledge of its chemical properties. Recent observations in the variability of carbon to ${ }^{234} \mathrm{Th}$ ratios in different particle types, as well as of associations of Th(IV) with various marine organic biomolecules has led to the need for a review of current knowledge and what future endeavors should be taken to understand the marine chemistry of thorium. (C) 2005 Elsevier B.V. All rights reserved.
\end{abstract}

Keywords: Thorium; Speciation; Seawater; Colloids; Exopolymeric substances; Transparent exopolymeric particles; Amphiphiles; Biosurfactant ligand

\footnotetext{
* Corresponding author.

E-mail addresses: santschi@tamug.edu (P.H. Santschi),jmurray@u.washington.edu (J.W. Murray), baskaran@wayne.edu (M. Baskaran), cbnelson@geol.sc.edu (C.R. Benitez-Nelson), guol@iarc.uaf.edu (L.D. Guo), hungc@tamug.edu (C.-C. Hung), clamborg@whoi.edu (C. Lamborg), moran@gso.uri.edu (S.B. Moran), upassow@awi-bremerhaven.de (U. Passow), Matthieu.Roy-Barman@1sce.cnrs-gif.fr (M. Roy-Barman).

${ }^{1}$ Current address: Department of Marine Science, University of Southern Mississippi, Stennis Space Center, MS 39529, United States.

${ }^{2}$ Current address: Institute of Marine Environmental Chemistry and Ecology, National Taiwan Ocean University, Keelung, 20224, Taiwan, Republic of China.
} 


\section{Introduction}

The element thorium (Th) is composed of 25 radioisotopes, ranging in atomic mass from 212 to 236, with half-lives of seconds to $10^{10}$ years (Table 1). Natural Th consists almost entirely of primordial ${ }^{232} \mathrm{Th}\left(t_{1 / 2}=1.4 \times\right.$ $10^{10}$ years), due to its extremely long half-life relative to the other Th isotopes. As such, when chemical equilibrium is established, ${ }^{232} \mathrm{Th}$ determines the chemical fate and speciation of all Th isotopes. In seawater, ${ }^{232} \mathrm{Th}$ is present at $\mathrm{pM}$ concentrations. A number of other Th isotopes (e.g. ${ }^{234} \mathrm{Th},{ }^{230} \mathrm{Th},{ }^{228} \mathrm{Th}$ ) also exist in seawater, albeit at lower concentrations, e.g. ${ }^{234} \mathrm{Th}$ is present in the ocean at atto-molar $\left(10^{-18} \mathrm{M}\right)$ concentration levels. These Th isotopes are primarily produced by natural uranium isotopes $\left({ }^{238} \mathrm{U},{ }^{235} \mathrm{U}\right.$ and $\left.{ }^{234} \mathrm{U}\right)$ that are soluble in seawater. In marine systems, Th has proven to be a very useful tracer of a wide range of oceanographic processes ranging from particle cycling (Bacon and Rutgers van der Loeff, 1989; Clegg and Whitfield, 1990, 1991; Dunne et al., 1997) and carbon export flux (e.g., Murray et al., 1989; Buesseler, 1998, and references therein; Benitez-Nelson et al., 2001) to boundary scavenging (Moore, 1981; Anderson et al., 1994; Santschi et al., 1999, Smoak et al., 2000) and paleocirculation (Yu et al., 1996; Marchal et al., 2000; Moran et al., 2002). This is because Th's chemical properties are relatively simple: Th has only one stable oxidation state, $\mathrm{IV}$, under all redox conditions in natural waters, and Th (IV) ions are extremely particle reactive.

Over the past several decades, one isotope of Th, ${ }^{234} \mathrm{Th}\left(t_{1 / 2}=24.1\right.$ days $)$, has been increasingly used as a tracer of short-term particle and carbon removal from the upper ocean via sinking particles. Organic carbon export or "export production" is often assumed, at steady state, to be equal to the flux of new nutrients into the euphotic zone. In essence, once ${ }^{234} \mathrm{Th}$ is pro- duced (via decay of ${ }^{238} \mathrm{U}$ ) in seawater, it is rapidly "scavenged" by the surrounding particle regime within days to few months. In its most basic sense, the difference between the ${ }^{234} \mathrm{Th}$ produced from ${ }^{238} \mathrm{U}$ and what is actually measured in the water, can be assumed to be due to removal by sinking particles (Savoye et al., 2006-this issue). This ${ }^{234} \mathrm{Th}$ flux is then used with a site and time specific carbon $(\mathrm{C}){ }^{234} \mathrm{Th}$ ratio to convert ${ }^{234} \mathrm{Th}$ fluxes into those of $\mathrm{C}$. Other elemental and compound fluxes can be calculated using the same approach (e.g., Bacon et al., 1996; Gustafsson et al., 1997a,b; Rutgers van der Loeff et al., 2002; Weinstein and Moran, 2005). Measured $\mathrm{C} /{ }^{234} \mathrm{Th}$ ratios vary significantly with region, season, depth and sample type, and reasons for this variability remain poorly understood (see Buesseler et al., 2006-this issue). Thus, as the use of ${ }^{234} \mathrm{Th}$ as an export tracer becomes more wide spread, it is essential that we understand the mechanisms that control its particle reactivity beyond the typical "blackbox" approach. At the very least, an improved knowledge of the chemical speciation of $\mathrm{Th}$ would allow one to better resolve and assess the variability of $\mathrm{C} /{ }^{234} \mathrm{Th}$ ratios, as well as its use as a probe of other biogeochemical processes in the ocean.

\section{Inorganic Th speciation}

The prevailing inorganic species of Th in seawater at $\mathrm{pH}$ of 8 are hydroxo (Choppin and Wong, 1998) and carbonato complexes, in approximately equal proportions (Bruno, 1990; Östhols et al., 1994; Murphy et al., 1999). In fact, in organic-free solutions, thorium, an A-type metal ion, will strongly hydrolyze to form polyhydroxy colloidal complexes. Other strong ligands include carbonate, humics, phosphate, ethylene-diaminetetraacetic acid (EDTA) and diethyl-triamine-pentaacetic acid (DTPA) (Tables 2a and 2b). The solubility of Th

Table 1

Radioisotopes of thorium (NAS-NS-3004, 1960; http://www.hps.org/publicinformation/radardecaydata.cfm?Element=Th)

\begin{tabular}{lllll}
\hline Isotope & Half-life & Type of decay & Main decay energy $(\mathrm{MeV})$ & Method of production \\
\hline${ }^{234} \mathrm{Th}$ & 24.1 days & $\beta^{-}$ & $0.053(70 \%)$ & Natural radioactivity; daughter of ${ }^{238} \mathrm{U}$ \\
${ }^{233} \mathrm{Th}$ & $22.1 \mathrm{~min}$ & $\beta^{-}$ & $1.245(87 \%)$ & ${ }^{232} \mathrm{Th}+$ neutrons \\
${ }^{232} \mathrm{Th}$ & $1.39 \times 10^{10}$ years & $\alpha$ & $4.012(78 \%)$ & Natural thorium is $100 \%{ }^{232} \mathrm{Th}$ \\
${ }^{231} \mathrm{Th}$ & $25.64 \mathrm{~h}$ & $\beta^{-}$ & $0.080(37 \%)$ & Natural radioactivity; daughter of ${ }^{235} \mathrm{U}$ \\
${ }^{230} \mathrm{Th}$ & $7.5 \times 10^{4}$ years & $\alpha$ & $4.687(76 \%)$ & Natural radioactivity; daughter of ${ }^{234} \mathrm{U}$ \\
${ }^{229} \mathrm{Th}$ & 7340 years & $\alpha$ & $4.845(56 \%)$ & Daughter of ${ }^{233} \mathrm{U}$ \\
${ }^{228} \mathrm{Th}$ & 1.9 years & $\alpha$ & $5.423(72 \%)$ & Natural radioactivity; daughter of ${ }^{228} \mathrm{Ac}$ \\
${ }^{227} \mathrm{Th}$ & 18.17 days & $\alpha$ & $6.038(24 \%)$ & Natural radioactivity; daughter of ${ }^{227} \mathrm{Ac}$ \\
${ }^{226} \mathrm{Th}$ & 30.9 min & $\alpha$ & $6.337(76 \%)$ & Daughter of ${ }^{230} \mathrm{U}$ \\
${ }^{225} \mathrm{Th}$ & $8 \mathrm{~min}$ & $\alpha$ & $6.48(43 \%)$ & Daughter of ${ }^{229} \mathrm{U}$ \\
${ }^{224} \mathrm{Th}$ & $\sim 1 \mathrm{~s}$ & $\alpha$ & $7.17(81 \%)$ & Daughter of ${ }^{228} \mathrm{U}$ \\
${ }^{223} \mathrm{Th}$ & $\sim 0.7 \mathrm{~s}$ & $\alpha$ & $7.29(60 \%)$ & Daughter of ${ }^{227} \mathrm{U}$ \\
\hline
\end{tabular}


depends on the structure of the $\mathrm{ThO}_{2}$ solid. For example, the solubility of crystalline $\mathrm{ThO}_{2}$ is $\sim 10^{-15} \mathrm{M}$ (Fanghänel and Neck, 2002; Neck et al., 2003), well below the observed $10^{-12} \mathrm{M}$ seawater ${ }^{232} \mathrm{Th}$ concentrations (Huh et al., 1989, and references therein). In contrast, the observed solubility of all forms of Th oxyhydroxides, including $\mathrm{Th}(\mathrm{OH})_{4}(\mathrm{am})$, ranges from $10^{-8}$ to $10^{-10}$ $\mathrm{M}$, due to conversion of larger crystalline forms to smaller amorphous colloidal forms during the dissolution and/or precipitation process (Fanghänel and Neck, 2002; Neck et al., 2003).

Sorption of ions to particle surfaces is strongly $\mathrm{pH}$ dependent, with cations generally showing increasing sorption with increasing $\mathrm{pH}$, and anions showing increasing sorption with decreasing $\mathrm{pH}$ (Stumm and Morgan, 1996). For example, maximum sorption of Th(IV) sorption to silica glass surfaces occurs at $\mathrm{pH} 4$ (Östhols, 1995). Thorium generally complexes to particle surfaces with inner-sphere complexes, as is evident from the ionic strength insensitivity of the Th(IV) sorption edge to hematite (Quigley et al., 1996), and from EXAFS studies of Th(IV) sorbing onto a silica surface

Table 2a

List of $\mathrm{p} K_{\mathrm{a}}$ values and stability constants for thorium/ligand complexes $\mathrm{Th}^{4+}+\mathrm{L}^{n-}=\mathrm{ThL}\left({ }^{4-n}\right)^{+}$

\begin{tabular}{|c|c|c|c|c|}
\hline Ligand & $\log \beta_{1}$ & $\log \beta_{2}$ & Reference $^{\mathrm{a}}$ & $\begin{array}{l}\mathrm{p} K_{\mathrm{a} 1}\left(\mathrm{p} K_{\mathrm{a} 2}\right) \\
\text { of acid }\end{array}$ \\
\hline Acetic acid & 3.1 & & 2 & 4.72 \\
\hline $\begin{array}{l}\text { Benzo-1,3-dioxole-2, } \\
\text { 2-diphosphonic acid }\end{array}$ & 16.4 & & 2 & $1.9(6.35)$ \\
\hline $\begin{array}{l}\text { Catechol, 1,2-dihydroxy } \\
\text { benzene }\end{array}$ & 5.5 & & 4 & $9.3(13.3)$ \\
\hline $\mathrm{CDTA}^{4-}$ & 25.6 & & 2 & $2.4(3.5)$ \\
\hline Citric acid $^{3-}$ & 13.0 & & 1,2 & 3.06 \\
\hline $\mathrm{Cl}^{-}$ & 0.36 & & 1 & -7 \\
\hline $\mathrm{CO}_{3}^{2-\mathrm{a}}$ & 11.0 & & 1 & $6.3(10.25)$ \\
\hline DTPA & 27.1 & & 2,4 & $2.0(2.6)$ \\
\hline EDTA $^{4-}$ & 23.2 & & 2 & $1.70(2.6)$ \\
\hline EGTA $^{4-}$ & 20.5 & & 2 & $2.0(2.66)$ \\
\hline $\mathrm{F}^{-}$ & 7.3 & 3.2 & 1 & 3.2 \\
\hline HEDTA $^{3-}$ & 17.0 & & 2 & $2.51(3.6)$ \\
\hline $\mathrm{HPO}_{4}^{2-}$ & 10.8 & 22.8 & 1 & $2.15(7.2)$ \\
\hline Humic acids & $10-11$ & $15-17$ & 3 & 4.5 \\
\hline IDA & 9.69 & & 2 & $2.6(9.2)$ \\
\hline Malonic acid & 7.58 & & 2 & $2.85(5.07)$ \\
\hline $\mathrm{NO}_{3}^{-}$ & 0.94 & 2.0 & 1 & -1.4 \\
\hline $\mathrm{NTA}^{2-}$ & 15.2 & & 2 & $1.9(2.5)$ \\
\hline $\mathrm{OH}^{-\mathrm{b}}$ & 10.2 & 20.0 & 1 & 14 \\
\hline Oxalic acid & 9.3 & 18.5 & 1 & $1.2(4.2)$ \\
\hline $\mathrm{SO}_{4}^{2-}$ & 3.67 & & 1 & $-9(2.0)$ \\
\hline Succinic acid & 6.44 & & 2 & 4.2 \\
\hline
\end{tabular}

a (1) Langmuir and Herman (1980) and Choppin and Stout (1989). (2) Martell and Smith (1990) and Smith and Martell (1989). (3) Nash and Choppin (1980). (4) Hirose and Tanoue (2001).

${ }^{\mathrm{b}}$ For ternary complexes, see Table $2 \mathrm{~b}$.
Table $2 b$

Hydrolysis constants used for fitting corrected to $0.5 \mathrm{M} \mathrm{NaClO}_{4}$ (Table 4 from Östhols et al., 1994).

\begin{tabular}{lllc}
\hline$p$ & $\mathrm{q}$ & $\mathrm{r}$ & $\log \beta_{p, q, r}$ \\
\hline 0 & 1 & 0 & -13.75 \\
0 & 1 & 1 & -7.57 \\
0 & 1 & 1 & $-17.23^{\mathrm{a}}$ \\
1 & 1 & 0 & -4.16 \\
1 & 3 & 0 & -11.22 \\
1 & 4 & 0 & -15.95 \\
2 & 2 & 0 & -6.71 \\
2 & 3 & 0 & -8.22 \\
\hline
\end{tabular}

All equilibria as: $p \mathrm{Th}^{4+}+q \mathrm{H}_{2} \mathrm{O}+r \mathrm{CO}_{2}(\mathrm{~g})=\mathrm{Th}_{p}(\mathrm{OH})_{q}\left(\mathrm{CO}_{2}\right)^{(4 p-q)+}$ $+q \mathrm{H}^{+}$

${ }^{a}$ Second acidity constant for $\mathrm{H}_{2} \mathrm{CO}_{3}$, i.e., $\mathrm{CO}_{2}+\mathrm{H}_{2} \mathrm{O}=\mathrm{CO}_{3}^{2}+2 \mathrm{H}^{+}$.

(Östhols et al., 1997). However, it should be noted that at the high metal to sorption site loadings necessary for the application of synchrotron radiation techniques, generally only the weaker binding sites are probed. This is because there is a continuous distribution function of metal-surface complex formation constants; stronger ligands are rarer than weaker ones (Buffle, 1990; Town and Filella, 2000, and references therein), a phenomenon which is most prevalent for humic and fulvic acid type compounds.

\section{Organic Th speciation}

There are few studies that have focused directly on organic ligand complexation of Th in natural waters. In general, they indicate that Th forms strong complexes with humic acids (Nash and Choppin, 1980; Choppin and Nash, 1981; Artinger et al., 2003; Reiller et al., 2003) and acid polysaccharides (Guo et al., 2002b; Quigley et al., 2002; Passow et al., 2006-this issue). Murphy et al. (1999) used laboratory experiments to demonstrate that in the presence of humic acids (Perdue et al., 1980) and acid polysaccharide-containing colloidal organic matter (COM) (Santschi et al., 1995), Th(IV) sorption to hematite was greatly enhanced. In fact, thorium is an element that generally shows high concentrations in colloidal fractions in marine environments (Guo and Santschi, 1997, and references therein). Together, these observations suggest that sorption of metal ions is enhanced in cases where the organic acid is strongly sorbed to particle surfaces (such as hematite, or clay minerals with humic compounds on their surface; Mayer, 1994, 1999). Since natural particles in seawater are coated with an organic film at the surface, they are mostly negatively charged (Hunter and Liss, 1979). Thus, it can be expected that metal ion sorption to inorganic surfaces is modified by dissolved organic compounds and dependent on the relative abundance 
and binding energies of functional groups on particle and in solution phases. If fulvic acid partitions mostly to the solution phase in the presence of inorganics, as is the case for silica, then Th(IV) sorption to particles is depressed (Moulin and Moulin, 2001; Moulin et al., 2004). Regardless, when negatively charged natural organic matter (NOM), such as humic acid, sorbs to a metal oxide or silicate surface, there is usually a $\mathrm{pH}$ optimum at low $\mathrm{pH}$, below which sorption decreases again due to competition with protons.

It appears that complex formation in solution between ${ }^{234} \mathrm{Th}(\mathrm{IV})$ and low molecular weight organic ligands is strongest for dicarboxylic acid and DTPAtype ligands (Table 2a). Information given in Table 2a for infinite dilution conditions, needs to be, of course, adjusted for seawater conditions using appropriate activity coefficient data. Nonetheless, this information provides a basis for our current understanding of organic-Th complexes, since very little data are available for macromolecular ligands. Hirose (1996) and Hirose and Tanoue $(1998,2001)$ reported conditional stability constants of Th(IV) of $10^{6.6}$ to $10^{7.1}\left(\mathrm{M}^{-1}\right)$ to the "strong" organic ligand found on colloid, particle and microorganism surfaces in seawater at $\mathrm{pH}$ of 1 , a value that is similar to that of DTPA at this $\mathrm{pH}$ (Hirose and Tanoue, 1998). Quigley et al. (2002) reported that Th(IV) binds to "sticky" (i.e., surface active, or surfactant-like), acidic polysaccharide-containing marine colloidal organic macromolecules of $\sim 13 \mathrm{kDa}$, which had high particle/water partition coefficients $\left(K_{\mathrm{d}}\right.$ or $K_{\mathrm{c}}$ for particles or colloids, respectively) of $10^{8}$ (L/kg-polysaccharides), and conditional stability constants of $10^{7.8}$ $\left(\mathrm{M}^{-1}\right)$ at $\mathrm{pH}$ of 8 , a value that is even higher than that of DTPA (Hirose and Tanoue, 1998). $K_{\mathrm{d}}\left(\right.$ or $K_{\mathrm{c}}$ ) is defined here as the operationally determined ratio of concentration on particles or colloids ( $\mathrm{mol} / \mathrm{kg}$ ) to that in the water $(\mathrm{mol} / \mathrm{L})$, while the conditional stability here is the formation constant of a 1:1 complex at a given $\mathrm{pH}$. This calculated conditional stability constant of $10^{7.8}$ $\left(\mathrm{M}^{-1}\right)$ is about an order of magnitude higher than the values for $\mathrm{pH}$ of 1 reported by Hirose and Tanoue (2001), which is not surprising given the difference in $\mathrm{pH}$ values.

In addition to Th(IV) binding to high molecular weight biomolecules, Quigley et al. (2002) and Alvarado-Quiroz et al. (2006-this issue) also reported Th(IV) binding to low-molecular weight organic ligands, most likely during times of cell lysis. Field observations by Guo et al. (1997) have also inferred the existence of lowmolecular Th(IV)-complexing ligands from the inverse dependency of colloid-water partition coefficients $\left(K_{\mathrm{c}}\right)$ with increasing colloid (COC) concentrations.
The existence of ligand groups in biomolecules that have a binding affinity for Th may be related to structural conformation, as many macromolecular organic compounds appear to be stabilized by metal ions. For example, $\mathrm{Mg}$ (II) and $\mathrm{Ca}$ (II) play a role in the complex formation of ATP and DNA, where they, as well as other metal ions, play a critical role in conformation stabilization (Ahmad et al., 2003; Deng et al., 2000). Given the similar ionic radii of $\mathrm{Th}(\mathrm{IV})$ and $\mathrm{Ca}(\mathrm{II})$ (i.e., $119 \mathrm{pm}$ for $\mathrm{Th}(\mathrm{IV})$ and $126 \mathrm{pm}$ for $\mathrm{Ca}$ (II) in 8-fold coordination, $108 \mathrm{pm}$ for $\mathrm{Th}(\mathrm{IV})$ and $114 \mathrm{pm}$ for $\mathrm{Ca}$ (II) in 6-fold coordination), it is possible that Th(IV) exchanges for $\mathrm{Ca}$ (II) in its coordination environments (e.g., the eggbox; Rees, 1972; Kohn, 1972; Moe et al., 1995), even though coulombic repulsion is about four times higher for Th(IV) (due to the higher charge/radius ratio).

\section{Overview of Th particle sorption in seawater}

Thorium as an A-type metal ion has high binding constants to oxygen-containing ligands, which can occur in both solution and particle surfaces. Particlewater partitioning depends then, to a large extent, on whether the strong ligand group is in the solution or particle phase. The inorganic composition of seawater is relatively uniform, thus changes in inorganic speciation of Th do not influence sorption in the ocean, with the exception of extreme environments, such as Mono Lake, CA and Soap Lake, WA, which are highly alkaline and reduce Th sorption via strong carbonate complexation (e.g., Simpson et al., 1982; Anderson et al., 1982; La Flamme and Murray, 1987). Experimentally derived and operationally defined particle-water partition coefficients, $K_{\mathrm{d}}$, for Th adsorption to different solid phases, including colloids, are shown for seawater conditions in Table 3. Although data is limited, they indicate moderate values for inorganic phases, and exceptionally high binding (log $K_{\mathrm{d}}$ close to 8 ) to certain organic phases such as acidic polysaccharides (APS). APS compounds are produced by marine plankton and bacteria on their cell surface (termed cell envelope, slime or mucilage layer, sheat, or capsule), and their $K_{\mathrm{d}}$ values for $\mathrm{Th}(\mathrm{IV})$ are similar to, or higher than, those observed for Th sorption to suspended particles and phytoplankton (Fisher et al., 1987). High volume concentration factors of up to $10^{7}$ have also been observed for bacteria (Lee et al., 1993), which also have the highest binding constants for Th(IV) (Hirose and Tanoue, 2001). Quigley et al. (2002) demonstrated a strongly positive relationship between $K_{\mathrm{d}}$ of $\mathrm{Th}(\mathrm{IV})$ (Fig. 1; for other trace metals, Fig. 2) and colloidal polysaccharide, with values reaching up to $10^{8} \mathrm{ml} / \mathrm{g}$-polysaccharides when extrapolated to 
Table 3

Predicted fraction on particles $\left(f_{\mathrm{p}}\right)$ for ${ }^{234} \mathrm{Th}(\mathrm{IV})$ onto mineral phases in the open ocean, based on observed lab-based particle-water partition coefficients, $K_{\mathrm{d}}(\mathrm{L} / \mathrm{kg})$, and upper limits of observed field-based particulate concentrations, $C_{\mathrm{p}}(\mathrm{kg} / \mathrm{L})$, to be compared to observed $f_{\mathrm{p}}$ that range from 0.1 to 0.5

\begin{tabular}{|c|c|c|c|c|}
\hline $\begin{array}{l}\text { Mineral or } \\
\text { organic phase }\end{array}$ & $\log K_{\mathrm{d}}$ & References $^{\mathrm{a}}$ & $-\log C_{\mathrm{p}}$ & $f_{\mathrm{p}}$ (predicted) \\
\hline $\mathrm{SiO}_{2}$ & $3-5$ & 1 & 8 & $<10^{-3}$ \\
\hline $\mathrm{CaCO}_{3}$ & $4-5$ & 2,3 & 8 & $<10^{-3}$ \\
\hline $\mathrm{Al}_{2} \mathrm{O}_{3} /$ clays & $5.6-6.8$ & 4,8 & 9 & $<10^{-2}$ \\
\hline $\mathrm{FeOOH}$ & $5.1-5.8$ & 3,5 & 9 & $<10^{-3}$ \\
\hline $\mathrm{MnO}_{2}$ & $4.4-7.6$ & $3,6,8$ & 10 & $<10^{-2}$ \\
\hline $\begin{array}{c}\text { APS-EPS at } \\
100 \% \text { PS }\end{array}$ & 8 & 7 & 8 & 0.5 \\
\hline
\end{tabular}

a (1) Roberts and Santschi (unpublished data). (2) Edwards et al. (1987) and Cochran (1992). (3) Guo et al. (2002b). (4) Niven and Moore (1993). (5) Quigley et al. (1996). (6) Hunter et al. (1988). (7) Quigley et al. (2002). (8) Geibert and Usbeck (2004).

$100 \%$ polysaccharides. Polysaccharide content is used as a proxy for the presence of strong Th-binding ligands, which are present at considerably lower abundance than total polysaccharides (Hung et al., 2003a,b; Santschi et al., 2003). Interestingly, purified Th(IV)-binding colloid material with $100 \%$ polysaccharide content had modern $\Delta{ }^{14} \mathrm{C}$ values (Santschi et al., 1998), suggesting that the ${ }^{234} \mathrm{Th}(\mathrm{IV})$ binding polysaccharide entity is of recent origin.

A few laboratory studies have addressed the sorption behavior of Th tracers to natural particle surfaces under ambient conditions (e.g., Guo et al., 2002b; Geibert and Usbeck, 2004), but have failed to adequately consider the issue of ambient colloids and their interactions with pure surfaces, or the production of particulate phases of Th tracers from ambient, artifactual colloids produced through acid neutralization of the tracer. For example,

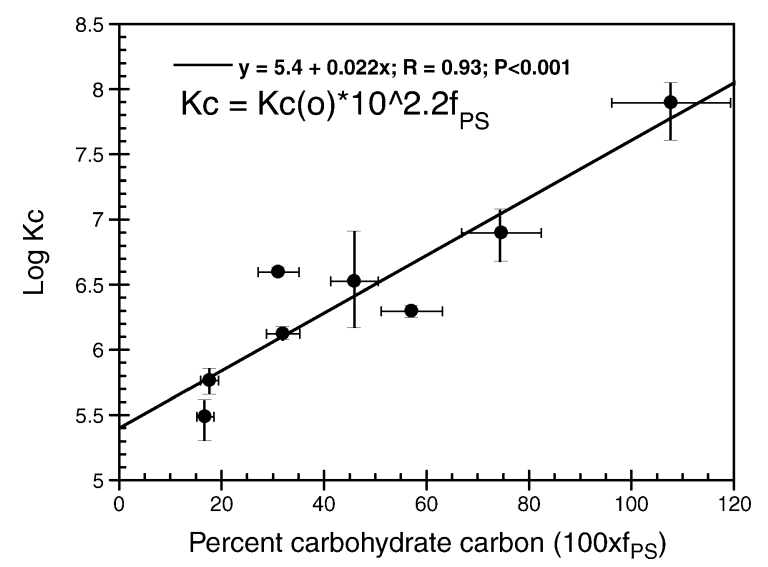

Fig. 1. Increased colloid-water partition coefficient $\left(K_{\mathrm{c}}=\right.$ ratio of activity on particles to that in solution) of ${ }^{234} \mathrm{Th}(\mathrm{IV})$ as a function of polysaccharide content, $f_{\mathrm{PS}}$ (Quigley et al., 2002).

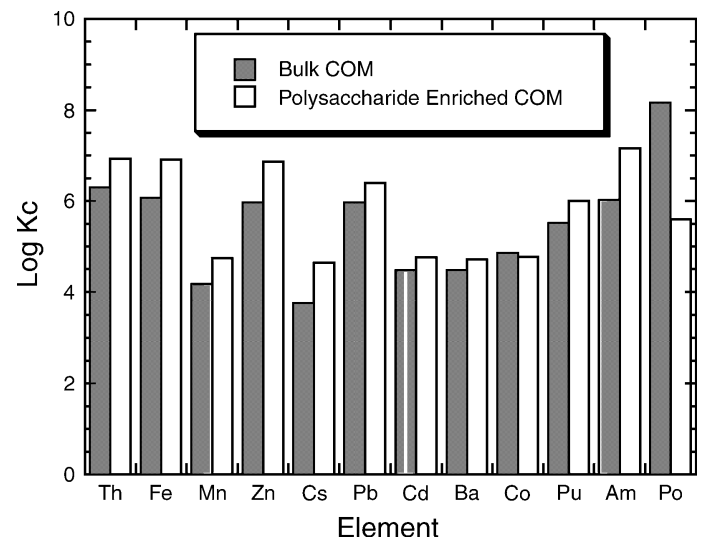

Fig. 2. Enhanced colloid-partition coefficient $\left(K_{\mathrm{c}}\right)$ to polysaccharideenriched colloidal organic matter (COM) over bulk COM (Quigley et al., 2002).

Geibert and Usbeck (2004) reported high particulate fractions of Th(IV) tracer in seawater solutions without any particle surfaces present. Particulate fractions of Th(IV) were considerably higher than when some of the particles (e.g., $\mathrm{CaCO}_{3}$ and $\mathrm{SiO}_{2}$ ) were present. Thus, reported particle sorption results were likely affected by the presence of ambient, artifact colloids, possibly produced during the neutralization of the Th tracer with $50 \% \mathrm{NaOH}$ before the experiment.

In order to predict the fraction of Th(IV) adsorbed to particles, one needs to also consider the concentration of the carrier phase (Table 3), and the "particle concentration effect", i.e., the inverse dependency of $K_{\mathrm{d}}$ on the particle concentration, which is discussed in detail in Honeyman et al. (1988) and Honeyman and Santschi (1989). Most importantly, however, given the low concentration of mineral phases in the ocean, high $K_{\mathrm{d}}$ values of $10^{7}(\mathrm{~L} / \mathrm{kg})$ or higher are needed to be consistent with the observation of $\geq 10 \%$ of ${ }^{234} \mathrm{Th}$ sorbed to suspended particles (e.g., Guo and Santschi, 1997; Buesseler, 1998; Buesseler et al., 2006-this issue, and references therein).

The low abundance of silica $\left(<10^{-8} \mathrm{~g} / \mathrm{L}\right)$, carbonate $\left(<10^{-8} \mathrm{~g} / \mathrm{L}\right)$, and $\mathrm{Fe}$ and $\mathrm{Mn}$ oxyhydroxides $\left(<10^{-9} \mathrm{~g} /\right.$ L) in the ocean, coupled with $\log K_{\mathrm{d}}$ values of 3-6 (with the higher values to natural rather than pure solids; Table 3), enables one to predict that only a small fraction of Th is adsorbed to marine particles, e.g., at most $10^{-3}$. However, when taking into account the $\log K_{\mathrm{d}}$ of $\sim 8$ for the polysaccharide-enriched fraction of marine organic matter (Quigley et al., 2002), and the abundance of polysaccharides (as a proxy) in the ocean of about $10^{-8} \mathrm{~g} / \mathrm{L}$ or higher (oligotrophic waters of the Gulf of Mexico: Guo et al., 2002a; Santschi et al., 2003; Hung et al., 2003a), one would predict the fraction of Th(IV) adsorbed to particles to be on the order of $50 \%$, close to 
published values, and at least 3 orders of magnitude higher than to pure inorganic surfaces. It is noteworthy that a $\log K_{\mathrm{d}}$ of about 8 is higher than that of the overall $K_{\mathrm{d}}$ of $\sim 7$ for natural particles in the ocean (e.g., Bacon et al., 1988; Guo et al., 1995, 1997; Murray et al., 2005).

The polysaccharidic, "sticky", surfactant-like Th(IV)complexing ligands, with a molecular weight of about $13 \mathrm{kDa}$, are likely embedded in a matrix of fibrillar exopolymeric particles (EPS) and transparent exopolymeric particles (TEP; Fig. 3) of much higher molecular weights. This is suggested by the close association of ${ }^{234} \mathrm{Th}$ with alcian blue stainable TEP and that ${ }^{234} \mathrm{Th}$ tracks colloidal TEP-precursors rich in APS. Furthermore, ${ }^{234} \mathrm{Th}$ tracks TEP, rather than total $\mathrm{C}$, from the colloidal (nm to $\mu \mathrm{m}$ ) to the marine snow ( $\mathrm{mm}$ to $\mathrm{cm}$ ) size range (Guo et al., 2002a; Santschi et al., 2003; Passow et al., 2006-this issue).

The fact that ${ }^{234} \mathrm{Th}$ and other Th isotopes also closely correlated with the abundance of biogenic opal (e.g., Ducklow et al., 2001; Buesseler et al., 2006-this issue), or $\mathrm{MnO}_{2}$ (e.g., Anderson et al., 1983), may not be an indication of high intrinsic adsorption capacities of these minerals, but rather an indication that diatoms are surrounded by an exopolymeric polysacchariderich gel (Decho, 1990; Leppard, 1995, 1997), with a sorption capacity potentially much higher than that of a pure silica surface. The correlation between the ${ }^{234} \mathrm{Th}$ deficit (with respect to production from ${ }^{238} \mathrm{U}$ decay) and occurrence of diatom blooms (Ducklow et al., 2001;
Buesseler et al., 2006-this issue) likely reflects the efficient export of particulate matter to depth by the ballast action of diatom frustules. The large ${ }^{234} \mathrm{Th}$ deficit under these conditions occurs despite the low affinity of Th for opal (Östhols, 1995; Chase et al., 2002), probably because of efficient particle export. In addition, the oxidation of $\mathrm{Mn}^{2+}$ to $\mathrm{MnO}_{2}$ in aquatic systems is microbially mediated, whereby high $\mathrm{MnO}_{2}$ concentrations are associated with bacterial EPS (Cowen and Bruland, 1985). These caveats do not, however, necessarily diminish the utility of single mineral phases as proxies for Th(IV) association to major carrier phases.

Both EPS and TEP are parts of the marine colloidal pool and are a major component of $\mathrm{mm}$ - to $\mathrm{cm}$-sized marine snow aggregates (panel on the right of Fig. 3). Marine snow has fractal properties (voids, self-similar, scaling invariant, settling velocity dependent on fractal dimension of aggregate) throughout the whole size spectrum (Alldredge and Gottschalk, 1988; Alldredge and Jackson, 1995). The fact that the marine snow aggregate abundance closely tracks ${ }^{234} \mathrm{Th} /{ }^{238} \mathrm{U}$ disequilibrium (Fig. 4) is another indication for their importance in ${ }^{234} \mathrm{Th}$ removal from the ocean. The inferred associations of Th isotopes with major inorganic phases (e.g., Chase et al., 2002; Luo and Ku, 2004) might be, as mentioned above, the result of organic, surface active substances coating inorganic minerals (Avnimelech and Troeger, 1982; Passow et al., 2006-this issue).

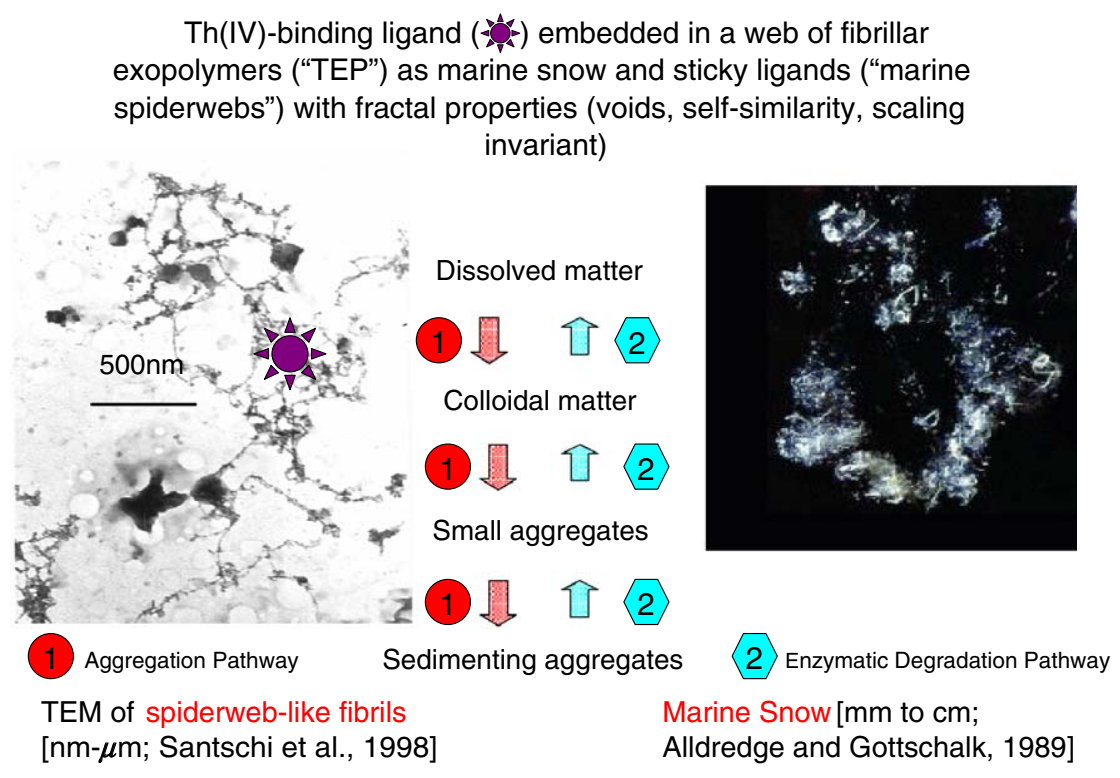

Fig. 3. Th(IV) binding ligand embedded in spiderweb-like fibrillar exopolymeric particles (TEP) occurring as colloids (left) and marine snow (right) showing fractal properties. It also shows the simultaneous flow of organic carbon (as degradation products) from large to small particles and macromolecules, and the coagulation and flocculation from small to large molecules and particles. 

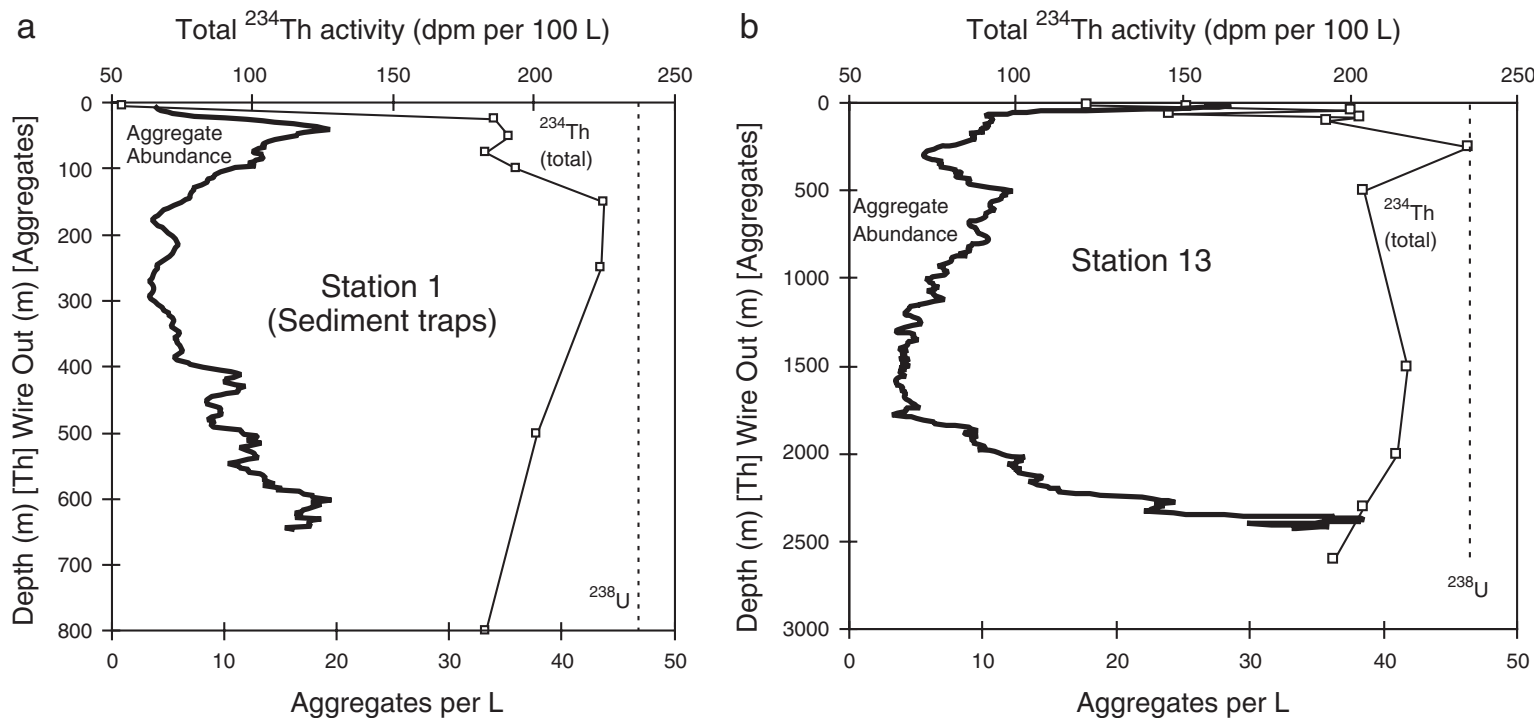

Fig. 4. ${ }^{234} \mathrm{Th}$ deficiencies in the water column as a measure of particle scavenging intensity in surface and deep waters of the Middle Atlantic Ocean (Santschi et al., 1999), closely correlating with the TEP-containing "marine snow" aggregate abundance (determined by in-situ camera), demonstrating a link between the two observations.

Th(IV) sorption to particles is classically treated as a reversible adsorption process (Bacon and Anderson, 1982; Clegg and Whitfield, 1990, 1991) and thermodynamic treatment of Th particle adsorption requires complete reversibility at the molecular level. For example, experimentally determined sorption rates converge to a constant particle-colloid-water distribution after hours to days (Nyffeler et al., 1984; Niven and Moore, 1993; Quigley et al., 2001), suggesting reversibility at a level between molecular and nanoscale. However, the rate of actual desorption at the molecular level, as observed in laboratory experiments, appears to occur at much slower rates. For example, Th(IV) desorption of low molecular weight species at $\mathrm{pH}$ of 8 does not occur at measurable rates from either hematite (Quigley et al., 1996) or natural colloidal particles (Quigley et al., 2001). This suggests hysteresis or partial irreversibility behavior at the ionic level, a sorption behavior that is common in aquatic systems (Everett and Whitton, 1952; Salomons, 1980; Comans et al., 1991). However, reversibility at the nanoscale has been demonstrated in laboratory experiments (Quigley et al., 1996, 2001).

It is interesting to note that regardless of the ${ }^{234} \mathrm{Th}$ tagged size class, i.e., low molecular weight marine colloids, high molecular weight marine colloids or suspended particles, all reach an equilibrium endstage that is indistinguishable from one another (Quigley et al., 2001). This information, coupled with the remarkably similar $K_{\mathrm{d}}$ and $K_{\mathrm{c}}$ values (and their particle concentration dependencies) of ${ }^{230} \mathrm{Th}$ and ${ }^{234} \mathrm{Th}$ isotopes between the dissolved and colloidal phase $\left(K_{\mathrm{c}}\right)$, and suspended particles $\left(K_{\mathrm{p}}\right)$ (e.g., Guo et al., 1995, 1997), suggests that the Th(IV)-binding ligand is surface active and can occur in all size fractions (Guo et al., 1997; Passow et al., 2006-this issue; AlvaradoQuiroz et al., 2006-this issue). It also implies that a dynamic equilibrium exists between Th(IV) in solution and particulate phases through an intermediate colloidal phase rather than at the ionic level. However, the surface-active behavior of the macromolecular ligand remains a challenge for the determination of binding constants for Th(IV), as the surfactant qualities of the ligand (e.g., Alvarado-Quiroz et al., 2006-this issue), which occur regardless of metal binding, need to be distinguished from the binding behavior of the Th ion during experiments.

\section{The role of marine colloids}

The abovementioned studies point to the significant role played by marine colloids in Th(IV) complexation. Colloids are typically defined as the material within the $1 \mathrm{~nm}$ to $1 \mu \mathrm{m}$ size class (Buffle, 1990; Kepkay, 1994). Colloidal organic $\mathrm{C}$ (COC), in particular, is rich in (acyl) polysaccharides, e.g., up to $80 \%$ (Aluwihare et al., 2002), and may represent one of the most reactive fractions of organic $\mathrm{C}$ within the upper ocean (Wells and Goldberg, 1992; Baskaran et al., 1992; Moran and Buesseler, 1992, 1993; Santschi et al., 1995). Acyl polysaccharides include $N$-acetyl and other ester groups, while the term acid polysaccharide only includes free acid groups (including $\mathrm{RCOO}^{-}, \mathrm{ROSO}_{3}^{-}$and $\mathrm{ROPO}_{3}^{2-}$ ). 


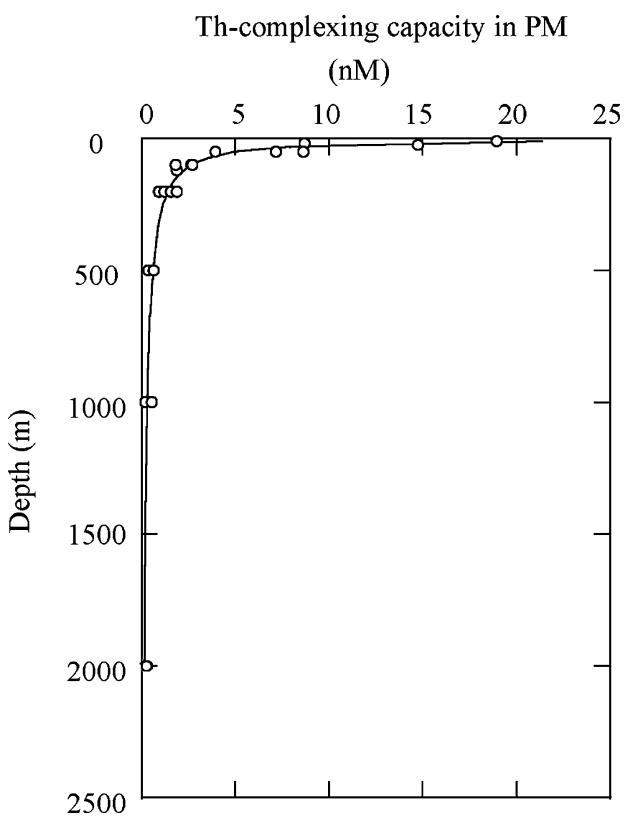

Fig. 5. Thorium complexing capacity (ThCC) in the North Pacific Ocean as a function of depth, with a profile similar to that of POC, PON, and proteins (Hirose and Tanoue, 1998).

Although colloidal ${ }^{234} \mathrm{Th}$ separation suffers from methodological issues (e.g., sampling protocols, ultrafiltration integrity, and correction factors, summarized in Guo and Santschi, 2005), a number of studies have indicated that between $0.04 \%$ and $80 \%$ of total ${ }^{234} \mathrm{Th}$ (Baskaran et al., 1992; Moran and Buesseler, 1992, 1993; Guo et al. 1997; Greenamoyer and Moran, 1997; Dai and Benitez-Nelson, 2001; Baskaran et al., 2003; Guo and Santschi, 2005, and references therein), and other Th nuclides (Zhang et al., 2005), are in the colloidal fraction either $>10 \mathrm{kDa}$ or $>1 \mathrm{kDa}$. The close association of Th with colloidal TEP-precursors, which are rich in acidic polysaccharides, suggests that ${ }^{234} \mathrm{Th}$ binds primarily to these substances, rather than to bulk carbon (Guo et al., 2002a,b; Passow et al., 2006-this issue).

In order to understand the role of colloids, it is first necessary to know more about the Th complexation capacity (ThCC) of colloidal and particulate organic matter. To this end, Hirose and Tanoue $(1994,1998)$ equilibrated $\mathrm{nM}$ to $\mu \mathrm{M}$ concentrations of ${ }^{232} \mathrm{Th}$ with $\sim 100 \mu \mathrm{g} / \mathrm{L}$ of particulate matter in a solution of $0.1 \mathrm{M}$ $\mathrm{HCl}$. The sorption of $\mathrm{Th}(\mathrm{IV})$ for varying total $\mathrm{Th}(\mathrm{IV})$ concentrations was modeled assuming a 1:1 complex with the particulate organic ligand. Results yield ligand concentrations (i.e., ThCC) and values for a conditional stability constant. Under those conditions $(\mathrm{pH}=1)$, the particle-water partition coefficient, $K_{\mathrm{d}}$, was about $10^{5} \mathrm{~cm}^{3} \mathrm{~g}^{-1}$. Hirose and Tanoue $(1994,1998)$ reported a ThCC (Th binding ligand concentration) of $20 \mathrm{nM}$ in suspended particles of the surface waters of the Pacific Ocean and $\sim 0.3 \mathrm{nM}$ in the deep ocean (Fig. 5) that closely correlated with the concentration of particulate ${ }^{232}$ Th (Fig. 6; Hirose, 2004). In the Pacific Ocean, ThCC in the "dissolved" phase (which includes the colloidal size fraction) was determined to be $\sim 3$ to $4 \mathrm{nM}$ in surface waters, and $\sim 2$ to $3 \mathrm{nM}$ in deep waters (Hirose, 1996). These colloidal and particulate ligand concentrations are $\sim 3$ orders of magnitude greater (as functional group concentration) than that of colloidal (Baskaran et al., 1992) or particulate ${ }^{232} \mathrm{Th}$, which are present at 0.1 to $1.5 \mathrm{pM}$ in seawater (Huh et al., 1989; Hirose, 2004), and several orders of magnitude lower than concentrations of POC $(1-10 \mu \mathrm{M}-\mathrm{C})$ or COC (10-40 $\mu \mathrm{M}-\mathrm{C})$ (Guo and Santschi, 1997).

Ratios of particulate organic ligand to OC were about $0.9-2.4 \mathrm{mmol} / \mathrm{mol}-\mathrm{C}$ in surface waters, and $0.2-0.6 \mathrm{mmol} / \mathrm{mol}-\mathrm{C}$ in deep waters (Hirose and Tanoue, 1998), this is similar to those in marine bacteria (2-4 mmol $/ \mathrm{mol}-\mathrm{C})$, zooplankton $(0.3 \mathrm{mmol} / \mathrm{mol}-\mathrm{C})$ and phytoplankton $(0.3 \mathrm{mmol} / \mathrm{mol}-\mathrm{C})$. ThCC values of bacteria, phytoplankton and zooplankton species were found to be proportional to the surface area to volume ratio of the organism (Hirose and Tanoue, 2001). For the colloidal organic ligands, one can calculate a total ligand/COC ratio of $0.1 \mathrm{mmol} / \mathrm{mol} \mathrm{C}$ (i.e., $3 \mathrm{nM}$ colloidal ligand $/ 30 \mu \mathrm{M}-\mathrm{C})$ in the surface ocean, and $0.2 \mathrm{mmol} / \mathrm{mol}-\mathrm{C}$ (i.e., $3 \mathrm{nM}$ colloidal ligand $/ 15 \mu \mathrm{M}-\mathrm{C}$ ) in the deep ocean from data given in Hirose (1996), Guo and Santschi (1997) and Benner (2002). If the organic ligand is an acid-polysaccharide-like molecule with about $1 \mathrm{meq} / \mathrm{g} \approx 12 \mathrm{meq} / \mathrm{mol}-\mathrm{C}$ of carboxylic acid groups, Th(IV)-binding macromolecular ligands would represent about $1 \%$ of COC.

What are these macromolecular chelating ligands made of? In general, we know relatively little about

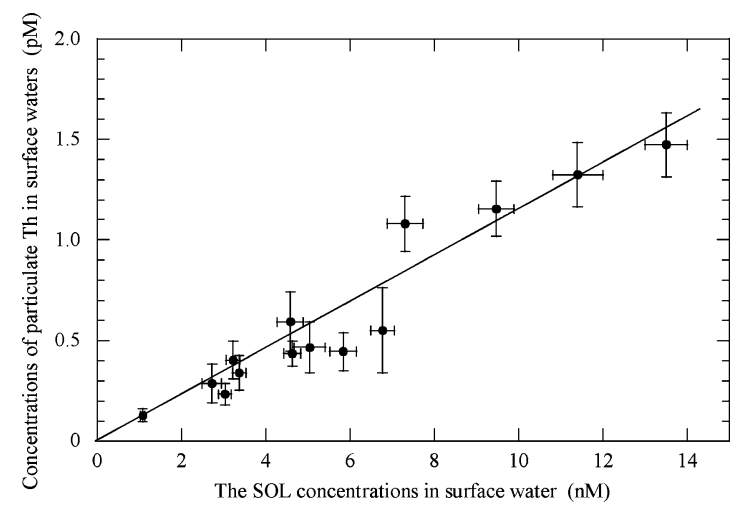

Fig. 6. Close correlation between particulate ${ }^{232} \mathrm{Th}$ and strong organic ligand (SOL) concentrations, resulting in a robust and constant ratio between the two concentrations (Hirose, 2004). 


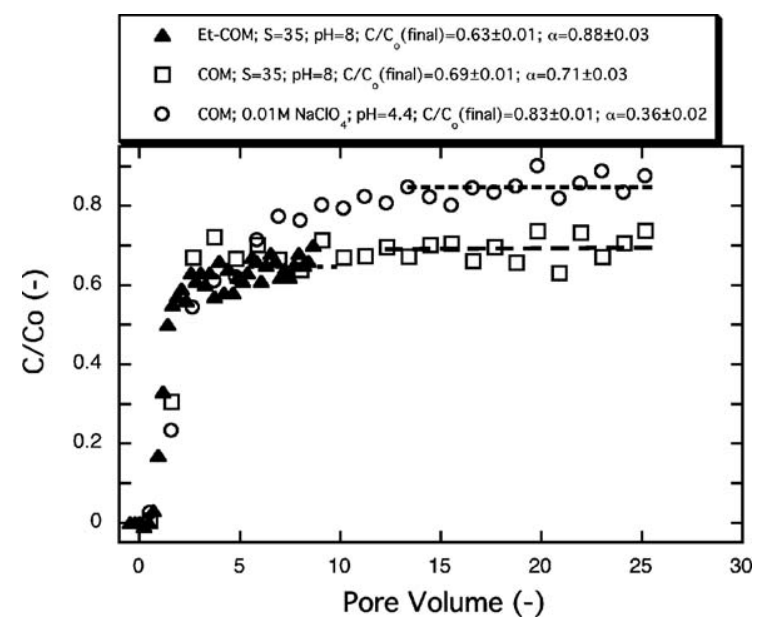

Fig. 7. Results from Quigley et al. (2001) demonstrating a high "sticky" factor, $a$, for polysaccharide-enriched colloidal organic matter. alpha ="sticky" or collision frequency factor, determined through modeling the brake through curve (Litton and Olson, 1993) and experimental data on tracer concentrations, average collector diameter and column length, porosity of glass bead column, and theoretical collector efficiency for transport by diffusion; whereby alpha=1 means that all collisions lead to an aggregate. The experimental data show glass bead column breakthrough curves of ${ }^{14} \mathrm{C}$-labeled colloidal organic carbon (COM, labeled on sugar-OH groups) in the effluent $(\mathrm{C})$ relative to the input ${ }^{14} \mathrm{C}$ activity $\left(\mathrm{C}_{0}\right) \cdot{ }^{14} \mathrm{C}$ - and ${ }^{234} \mathrm{Th}$ labeled colloids behaved very similarly in their sorption and transport behavior in gel electrophoresis separations and marine particle sorption experiments (Quigley et al., 2002). Thus, they can be assumed to be the same as for the Th(IV)-binding chelating macromolecular ligands. $\mathrm{COM}$ samples include ${ }^{14} \mathrm{C}$ labeled $\mathrm{COM}$ and polysaccharide-enriched COM (EtCOM) under different solution $\mathrm{pH}$ (8 and 4.4) and ionic strength (seawater of 35 salinity, or $0.01 \mathrm{M} \mathrm{NaClO}_{4}$ ) conditions (Quigley et al., 2001).

the physicochemical properties of colloids in marine systems, e.g., proton reactive sites, their $\mathrm{p} K_{\mathrm{a}}$ values, electrophoretic mobilities, and relative hydrophobicities (Doucet et al., 2006). Evidence suggests that macromolecular ligands that strongly bind Th(IV) and other metals are negatively charged, intermediate in molecular weight $(\sim 10 \mathrm{kDa})$, and surface active (high "sticky" coefficient, or alpha factor, of 0.9; Quigley et al., 2001; Fig. 7). The fact that Th-binding biomolecules contain both hydrophilic polysaccharides and hydrophobic proteins (Alvarado-Quiroz et al., 2006-this issue) also makes them amphiphatic (or amphiphilic), thus classifying them as biosurfactants and bioemulsifiers (Ron and Rosenberg, 2001). Also, they have a low $\mathrm{pH}_{\mathrm{IEP}}$ of $\sim 2$ to 4 and a $\mathrm{p} K_{\mathrm{a}}$ of $\leq 3$ (Muller, 1998; Santschi et al., 1998; Quigley et al., 2002; Alvarado-Quiroz, 2004; Alvarado-Quiroz et al., 2006-this issue). Finally, we know that they are part of the alcian blue stainable fraction of the particle and colloidal pool (Guo et al., 2002a; Passow et al., 2006-this issue). Santschi et al.
(1995) and Quigley et al. (2002) reported a total concentration of $1.3-1.4 \mathrm{meq} / \mathrm{g}$ of proton reactive sites in marine colloids from the Gulf of Mexico, which is intermediate between that of humic and fulvic acids (10-16 meq $/ \mathrm{g})$, alginate (5 meq $/ \mathrm{g})$, and aquatic polysaccharides (0.3 to $0.8 \mathrm{meq} / \mathrm{g}$ ) (Buffle, 1990). For modeling purposes, these proton-reactive sites are often assumed to contain $\mathrm{p} K_{\mathrm{a}}$ values of 2, 4, 6, 8, and 10 (e.g., Murphy et al., 1999). Actual values of $\mathrm{p} K_{\mathrm{a} 1}$ have been determined for aquatic colloids as $\leq 3$ (Muller, 1998, 1999; Santschi et al., 1998; Quigley et al., 2002), which suggests dicarboxylic acids, sulfate or polyphosphate as possible ligands. Values for $\mathrm{p} K_{\mathrm{a} 2}$ are more variable, and increase from $\sim 4$ to 9 across the salinity gradient in the Firth of Clyde estuary (Muller, 1998, 1999). This suggests that the nature of colloids changes dramatically across an estuarine salinity gradient. Measured electrophoretic mobilities of aquatic colloids are negative (at $\mathrm{pH} 8$, they range from -2 to $-3.410^{-8} \mathrm{~m}^{2} \mathrm{~V}^{-1} \mathrm{~s}^{-1}$ ), in agreement with the $\mathrm{p} K_{\mathrm{a}}$ values (Lead et al., 1999; Muller, 1998, 1999). The exact values of these parameters were weakly related to the colloidal fraction of metal-specific ligands (colloidal $\mathrm{C}_{\mathrm{L}} /$ total $\mathrm{C}_{\mathrm{L}}$ ), although $\mathrm{Cu}$ and $\mathrm{Pb}$ did relate in the opposite direction (Muller, 1998). In accordance with the relatively high concentration of moderately strong acidic sites, isoelectric points of marine colloids of about 2 to 4 have been determined by Quigley et al. (2002) and Alvarado-Quiroz et al. (2006-this issue), suggesting that the surface charge of marine colloids is dominated by relatively strong acidic groups. Positively charged ligand moieties (e.g., amino groups) are considerably rarer.

While marine colloids are negatively charged, suggesting hydrocolloid-like behavior, it does not preclude co-existence with more hydrophobic sites. Indeed, EPS and APS have been described as amphiphilic (Stenström, 1989; Buffle, 1990; Dickinson, 2003), due to the covalent binding of hydrophilic APS to the more lipophilic proteins and lipids (Leppard, 1995, 1997). Furthermore, it is likely that more hydrophobic regions of the ligand molecules would make them more particle-reactive or surfactant-like, giving them a shorter residence time in the water column. However, this has not yet been demonstrated in the field. Nonetheless, laboratory studies on bacterial attachment show a clear positive relationship between attachment probability and relative hydrophobicity of the bacterial surfaces (e.g., Stenström, 1989; Ahimou et al., 2001), which are composed of EPS. This leaves open the strong possibility that colloidal aggregation, i.e., coagulation, of organic matter and associated ${ }^{234} \mathrm{Th}$ is also dependent on the relative hydrophobicity of the biopolymers. 
Colloids are often present as aggregates. Recent observations of colloidal particles using transmission electron microscopy (TEM) (Leppard, 1997) and atomic force microscopy (AFM) (Santschi et al., 1998; Wilkinson et al., 1999) have revealed that an important fraction of colloidal organic matter in aquatic systems is present as nano-scale polysaccharide-rich fibrils that also contain smaller molecules assembled like pearls on a necklace (left panel in Fig. 3). These fibrils are rich in APS, have diameters of $1-3 \mathrm{~nm}$ and can be missed in the retentate if standard fractionation/ultrafiltration techniques are applied, or if the sample is not properly stained before TEM imaging (Santschi et al., 1998; Leppard, 1997). Fibrils have estimated molecular weights between $10^{5}$ and $10^{6} \mathrm{kDa}$ and yet, because of their shape, they have the ability to pass through $10 \mathrm{kDa}$ ultra filters (Santschi et al., 1998). These features illustrate the experimental difficulties one encounters when using operational procedures for studying the interactions of Th(IV) with APS containing ligands that are contained (or embedded) in EPS and TEP (Fig. 3).

The results reviewed above suggest a relatively low abundance of highly surface-active metal binding biopolymers (Santschi et al., 2003). This notion is confirmed by recent results that indicate that only a relatively minor fraction of the total carbohydrate content of marine suspended and sinking matter consists of surface-active APS compounds, with total uronic acids (URA) comprising $\sim 7 \%$ of the total carbohydrate (or $0.2-2 \%$ of POC), and total APS, $\sim 11 \%$ of the total carbohydrate, or about $1 \%$ of POC (Santschi et al., 2003; Hung et al., 2003a,b). These surface-active substances need only be present in small quantities to be effective in Th-binding. The content of more hydrophobic proteins in EPS is $2-3 \%$ for different phytoplankton species (e.g., Synechococcus elongates, Skeletonima costatum and Emiliania huxleyi; Hung and Santschi, unpublished results), and $2.6 \%$ for a marine bacterium (Sagittula stellata; Alvarado-Quiroz et al., 2006-this issue).

The exact role of the APS containing EPS molecules remains unknown, but their presence could reconcile the decade-old enigma of two sets of contradictory findings, i.e., between carbon flow from particulate and high molecular weight to low molecular weight molecules (Fig. 8; Alldredge et al., 1993; Amon and Benner, 1994; Santschi et al., 1995; Guo et al., 1996) and trace metal scavenging from dissolved to colloidal to particulate phases (e.g., Honeyman and Santschi, 1989). The relationship between Th and specific organic ligands, although only based on a few studies, allows for a major fraction of ${ }^{234} \mathrm{Th}$ to be transferred by coagulation up the

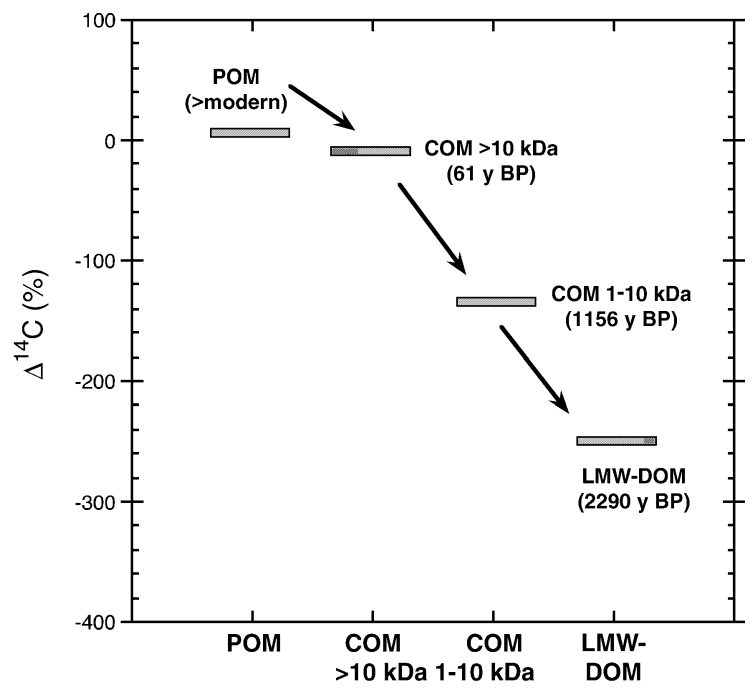

Fig. 8. Variations of $\Delta^{14} \mathrm{C}$ values between POM and different DOM fractions $\left(\mathrm{COM}>10 \mathrm{kDa}, \mathrm{COM}_{10}, \mathrm{COM}\right.$ between 1 and $10 \mathrm{kDa}$, $\mathrm{COM}_{1-10}$, and $<1 \mathrm{kDa}$ LMW-DOM) from surface waters in the Middle Atlantic Bight (replotted from Guo et al., 1996), demonstrating the general size-reactivity continuum that suggests carbon flow from particulate to colloidal to dissolved, and a younger $>10 \mathrm{kDa}$ COM fraction than the $1-10 \mathrm{kDa} C O M$ fraction.

particle size spectrum, from colloids to small, and then to large particles (e.g., Honeyman and Santschi, 1989; Baskaran et al., 1992; Quigley et al., 1996). This would have only a minor effect on the main carbon flow, which is from the breakdown of large to small molecules, as also deduced from the relative radiocarbon ages of the different size fractions (Fig. 8; Guo et al., 1996). Coagulation and fragmentation may be further modified by the enzymatic release of smaller fragments of fibrillar acidic polysaccharide containing EPS (Santschi et al., 1998; Passow, 2002) into the "dissolved" " phase, where they complex with freshly produced ${ }^{234} \mathrm{Th}$ and coagulate back into the particulate size fraction (Quigley et al., 2001). This would be consistent with concurrent coagulation and fragmentation processes. Furthermore, the relatively low and constant percentage of particulate polysaccharides that have acid functional groups (e.g., APS; Hung et al., 2003a) may also explain the correlation that was reported by Quigley et al., (2002) between the $\log$ of the conditional binding constant of ${ }^{234} \mathrm{Th}$ and the total polysaccharide content of the macromolecular organic matter.

\section{Th(IV) binding ligands and their influence on POC $/{ }^{234}$ Th ratios}

Specific field studies of the ${ }^{234} \mathrm{Th}(\mathrm{IV})$ confirm the importance of the APS containing EPS fraction. For 

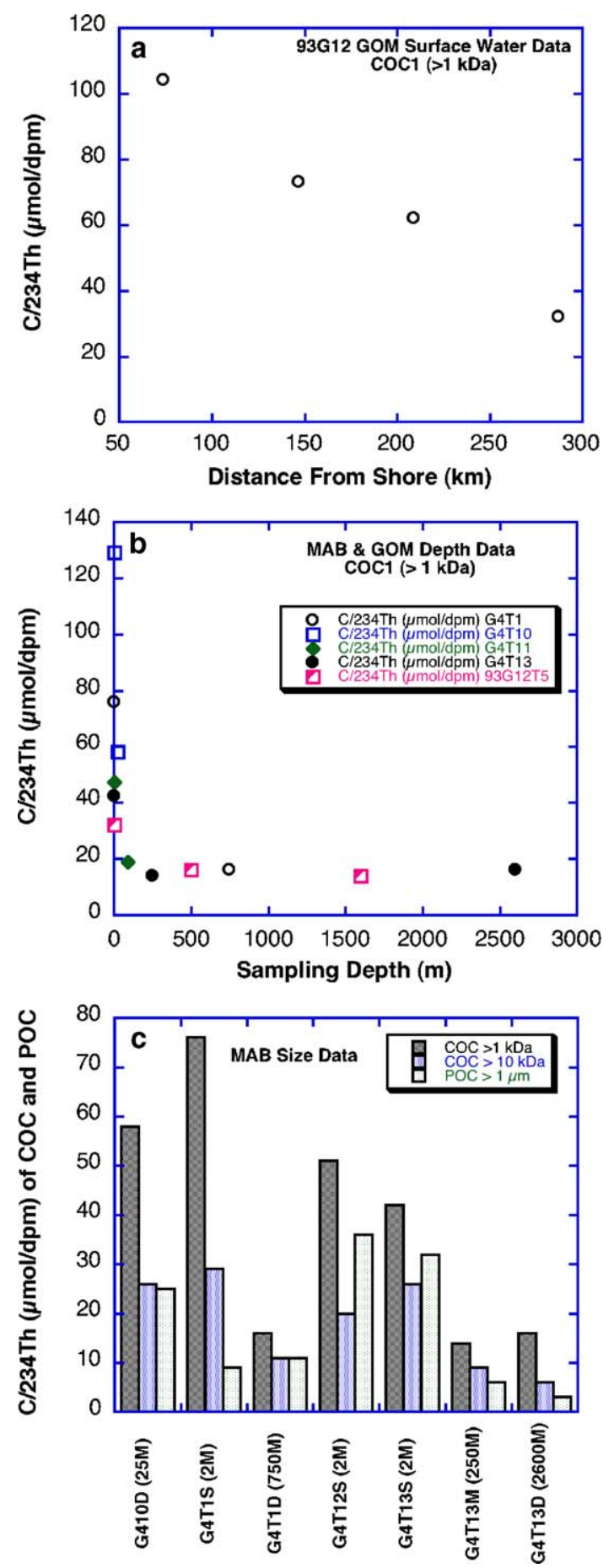

Fig. 9. $\mathrm{OC}^{234} \mathrm{Th}$ ratios of size-fractionated colloidal macromolecular $\mathrm{OC}(>1 \mathrm{kDa}$ and $>10 \mathrm{kDa}$ molecular weight cutoff) and POC from the Middle Atlantic Bight (MAB) and the Gulf of Mexico (GOM), calculated from data given in Guo et al. (1997), with sample descriptions given in Guo et al. (1996) and Santschi et al. (1995). They demonstrate a strong dependency of the $\mathrm{C} /{ }^{234} \mathrm{Th}$ ratios decreasing with increasing distance from shore (a), sampling depth (b), and size (c; $>1 \mathrm{kDa}(\sim 1$ $\mathrm{nm})$ to $0.2 \mu \mathrm{m},>10 \mathrm{kDa}(\sim 3 \mathrm{~nm})$ to $0.2 \mu \mathrm{m}$, and $>0.4 \mu \mathrm{m})$. example, the ${ }^{234} \mathrm{Th}(\mathrm{IV})$ content (and by implication, that of Th(IV)-binding ligands) of COM increases from low to higher MW POC, and C/ ${ }^{234}$ Th ratios decrease (Fig. 9; Guo et al., 1997). Such an observation is predicted by coagulation effects (e.g., Burd et al., 2000; Honeyman and Santschi, 1989). It also suggests that the molecular weight of the aggregate that contains the Th(IV)-binding surface-active ligand is higher than $10 \mathrm{kDa}$, as was suggested by the experimental data of Quigley et al. (2001, 2002). In addition, OC/ ${ }^{234} \mathrm{Th}$ ratios of colloids $\geq 1 \mathrm{kDa}$ calculated from Guo et al. (1997) consistently decrease (and C-specific ${ }^{234} \mathrm{Th}$ contents increase) from nearshore to offshore, and from surface water to deep waters (Fig. 9). Another study in the Santa Barbara Basin (Passow et al., 2006-this issue) agreed with the decreasing trend of $\mathrm{C}^{234} \mathrm{Th}$ ratio in the colloidal size range, and showed that the ratio of ${ }^{234} \mathrm{Th}$ to acidic polysaccharide rich TEP and precursors remained relatively constant over all suspended particle size fractions. As the fraction of TEP-precursors within the $\mathrm{C}$ pool increased with size, the $\mathrm{C} / \mathrm{Th}$ ratio decreased within the colloidal size range and showed little trend from very small to large suspended particles, but was lower in marine snow aggregates (Passow et al., 2006-this issue).

The results of Santschi et al. (2003) and AlvaradoQuiroz et al. (2006-this issue) indicate that ligands other than carboxylic groups, e.g., phosphate and sulfate, also contribute to binding of Th(IV). Thus, there can be several functional groups (e.g., carboxylate, phosphate, sulfate) that coincide with the Th(IV) peak in isoelectric focusing systems with tagged COM and EPS harvested from marine phytoplankton and bacteria. Th(IV)-binding ligands also had molecular weights that varied somewhat with species (Alvarado-Quiroz et al., 2006this issue). These results suggest that a family of clustered chelating ligand system exists with varying functional groups within an amphiphilic biosurfactant macromolecule of variable molecular weights. A macromolecular chelating ligand with DTPA-type building blocks (Hirose and Tanoue, 1998) would explain the strong Th(IV) binding that occurs even at $\mathrm{pH}$ of 1 .

Suggestions for the importance of a sticky, microbially derived Th(IV)-binding ligand are also derived from field observations. Lee et al. (1993) observed a correlation between the concentration of size-fractionated particulate ${ }^{234} \mathrm{Th}$ and the concentration of bacteria in the smallest size fraction and suggested that bacteria are important for ${ }^{234}$ Th binding. Baskaran et al. (1996) described relationships between phytoplankton pigment biomarker concentrations and particulate ${ }^{234} \mathrm{Th}$ activities, ${ }^{234} \mathrm{Th}$ deficiencies or removal rate constants, as well as a significant inverse correlation between the 
dissolved ${ }^{234} \mathrm{Th}$ concentration and DOC in the Gulf of Mexico that were attributed to enhanced removal of ${ }^{234} \mathrm{Th}$ by coagulation of bio-colloids. While Niven et al. (1995) are sometimes credited for suggesting that the extent of ${ }^{234} \mathrm{Th}$ bound to suspended matter is related to the concentration of TEP, they had no experimental data to support their theory. Later field observations, however, confirmed such a hypothesis, and also suggest a relationship between (1) abundance of large marine snow aggregate particles and ${ }^{234} \mathrm{Th}$ deficiencies (Fig. 4; Santschi et al., 1999); (2) the APS or uronic acid (URA) abundance and $\mathrm{C} /{ }^{234}$ Th ratios (Figs. 10 and 11; Guo et al., 2002a; Santschi et al., 2003; Passow et al., 2006-this issue); and (3) the abundance of prymnesiophytes and/or cyanobacteria and $\mathrm{C} /{ }^{234} \mathrm{Th}$ ratios (Fig. 12; Santschi et al., 2003). Baskaran et al. (1996) and Buesseler (1998), previously showed correlations between ${ }^{234} \mathrm{Th}$ distributions and those of individual phytoplankton pigments. Correlations between POC normalized polysaccharide fractions (total polysaccharides, CHO, uronic acids, URA and acid polysaccharides, APS) and $\mathrm{C}^{234} \mathrm{Th}$ in the Gulf of Mexico were significant at the $90-99 \%$ confidence level, and although correlation coefficients tended to be lower, they were highest (with $p \leq 0.02$ ) for sinking particles caught in sediment traps (Fig. 11; Santschi et al., 2003) suggesting that sinking particles may provide a more sorted assembly for calculating POC and APS fluxes. Average URA/POC and APS/POC ratios in sinking particles were similar to those in large $(>53 \mu \mathrm{m})$ suspended particles, but $\mathrm{C} /{ }^{234} \mathrm{Th}$ ratios were, on average, lower in the large particle size class $(>53 \mu \mathrm{m})$. Lower $\mathrm{C} /{ }^{234} \mathrm{Th}$ ratios for large particles $(>53 \mu \mathrm{m})$ (Hung et al., 2004), a particle size range that contains only a small fraction of the total POC, CHO, URA and APS pool (Hung et al., 2003a), are an indication that the Th(IV)binding molecules in this Gulf of Mexico study were enriched in larger particles, possibly as a consequence
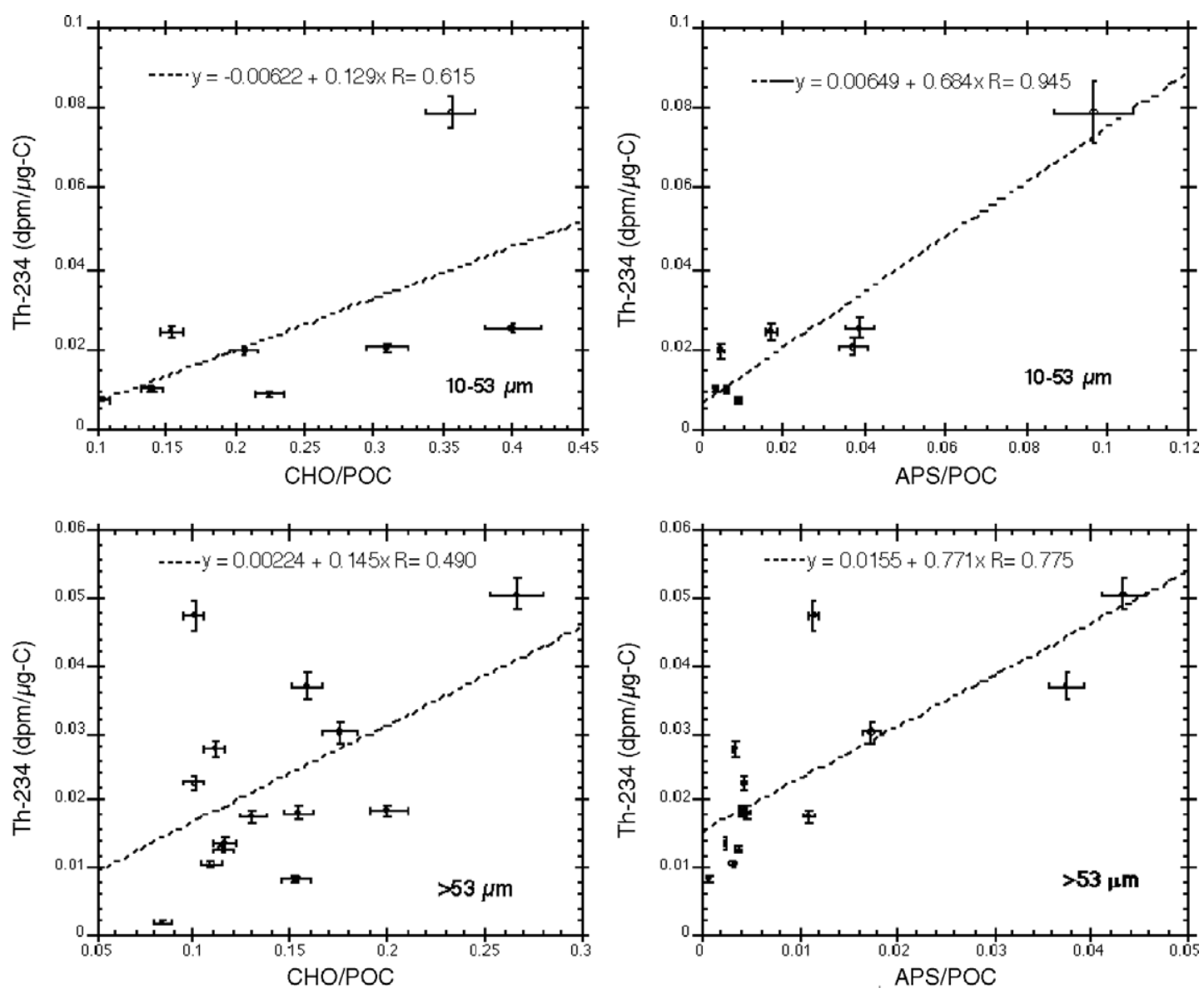

Fig. 10. Relationship between ${ }^{234} \mathrm{Th} / \mathrm{POC}$ ratio and POC-normalized acid polysaccharide (APS) and carbohydrate (CHO) concentrations (with $\mathrm{CHO} / \mathrm{POC}=f_{\mathrm{PS}}$, see text) during the July 2000 cruise to warm and cold core rings in the Gulf of Mexico (Guo et al., 2002a). 

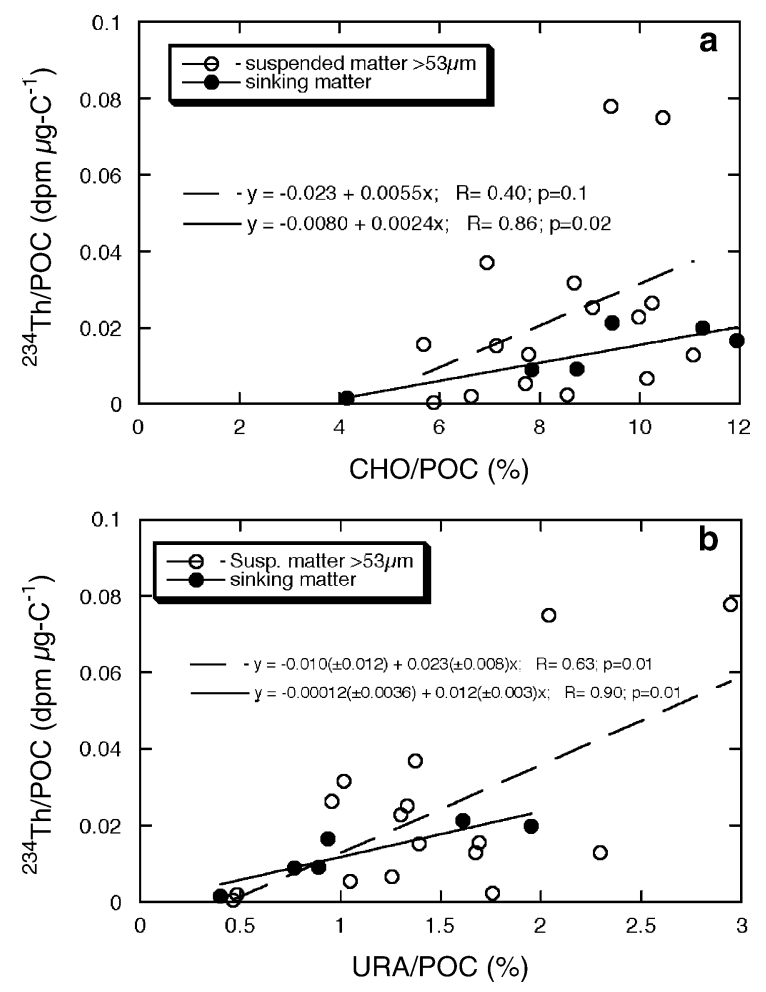

Fig. 11. (a) Relationship between ${ }^{234} \mathrm{Th} / \mathrm{POC}$ ratio and POC-normalized carbohydrate $(\mathrm{CHO})$ and (b) uronic acid (URA) concentrations (with $\mathrm{CHO} / \mathrm{POC}=f_{\mathrm{PS}}$, see text) during the May 2001 cruise to warm and cold core rings in the Gulf of Mexico (Santschi et al., 2003). Open circles are for suspended particles $>53 \mu \mathrm{m}$, and filled circles are for sinking particles from sediment traps deployed for 1 day at 65,90 , and $120 \mathrm{~m}$ water depths.

of sorption, coagulation or aggregation kinetics and microbial reactions. Thus, it appears that ${ }^{234} \mathrm{Th}$ is rapidly transported by coagulation from small to large colloids, and then by aggregation from small to large particles (Honeyman and Santschi, 1989), while the ${ }^{234} \mathrm{Th}$ content in sinking particles is diminished by enzymatic degradation of Th(IV)-binding APS compounds (Santschi et al., 2003). Lower $\mathrm{C} /{ }^{234}$ Th ratios in sinking particles compared to $>53 \mu \mathrm{m}$ particles are also observed when the clay content is high in sinking matter (Passow et al., 2006-this issue). In coastal regions a high abundance of clays, which may be coated by organic ligands, could increase Th-binding capacity relative to $\mathrm{C}$.

One might ask if the relationships between polysaccharide content and Th(IV)-binding (i.e., particle-water partition coefficient, $K_{\mathrm{d}}$ ) observed in the laboratory (Eq. (1), Quigley et al., 2002) can explain relationships between $\mathrm{C} /\left[{ }^{234} \mathrm{Th}_{\mathrm{p}}\right]$ ratio and polysaccharide content observed in field experiments (Guo et al., 2002a; Santschi et al., 2003; Hung et al., 2004). We can examine this relationship more closely using the following equation

$K_{\mathrm{d}}=K_{\mathrm{d}}(o) * 10^{\left(a_{\mathrm{PS}}\right)}\left(\mathrm{cm}^{3} \mathrm{~g}^{-1}\right)$

where $a$ is a constant, with a typical value of 2.2 (Quigley et al., 2002). Given the dissolved ${ }^{234} \mathrm{Th}$ concentration $\left(\left[{ }^{234} \mathrm{Th}_{\mathrm{d}}\right](\right.$ in $\left.\mathrm{dpm} / \mathrm{l})\right)$, suspended particulate matter concentration ([SPM] in $\mathrm{g} / \mathrm{L}$ ), POC (in $\mathrm{g}-\mathrm{OC} / \mathrm{L}$ ), the frac-
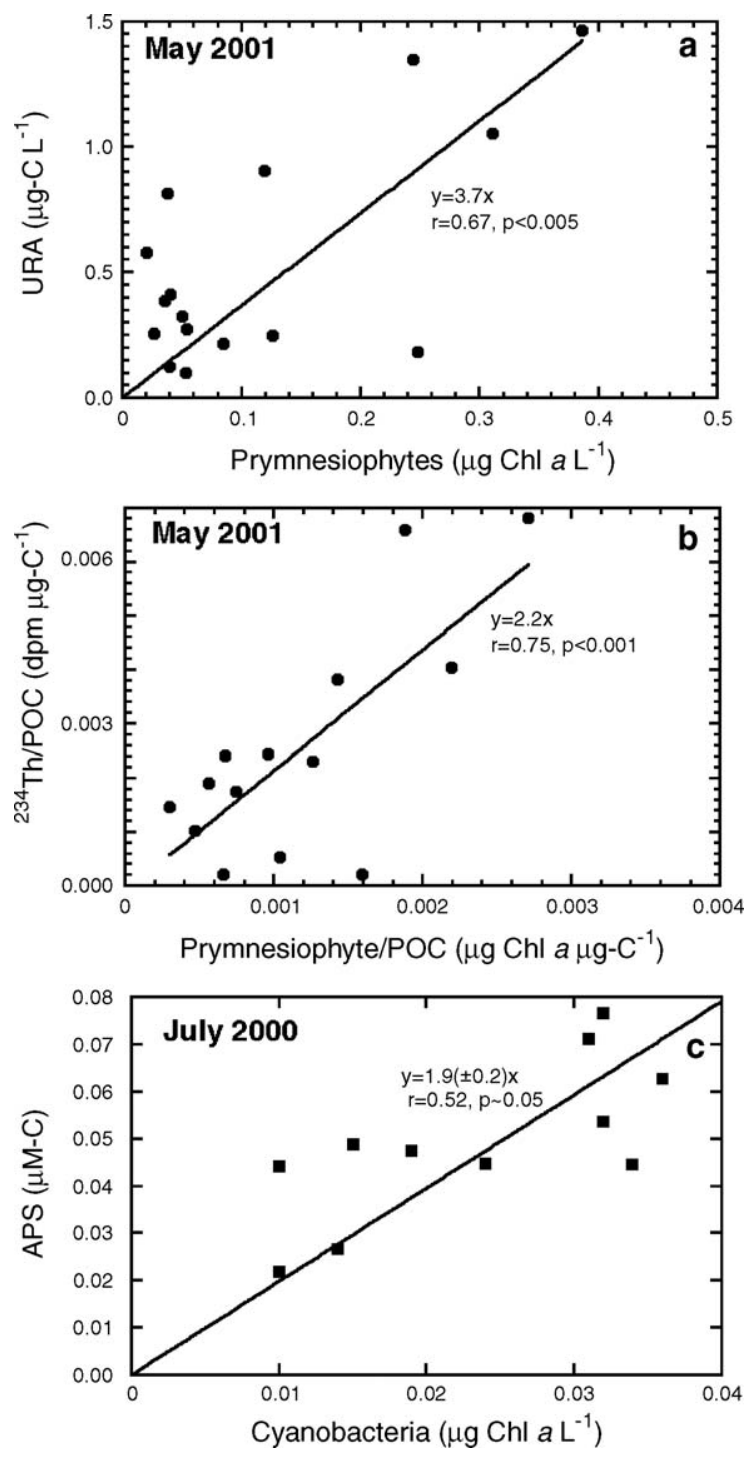

Fig. 12. (a) Relationship between abundance of prymnesiophytes in the Gulf of Mexico in May 2001 to the uronic acid (URA) concentration and (b) ${ }^{234} \mathrm{Th} / \mathrm{POC}$ ratio in May 2001, and (c) correlation between cyanobacteria abundance and APS concentration in July 2000, demonstrating that different phytoplankton species appear, at times, to control APS and URA production and ${ }^{234} \mathrm{Th}$ complexation (Santschi et al., 2003). 
tion of POC relative to bulk suspended particles $\left(f_{\mathrm{OC}}=\right.$ $[\mathrm{POC}] /[\mathrm{SPM}]$ in $\mathrm{g}-\mathrm{OC} / \mathrm{g}$ particles), and the fraction of polysaccharides relative to $\mathrm{POC}([\mathrm{CHO}] /[\mathrm{POC}]=[\mathrm{PS}] /$ $\left.[\mathrm{OC}]=f_{\mathrm{PS}}\right)$, we can rewrite the $[\mathrm{POC}] /\left[{ }^{234} \mathrm{Th}_{\mathrm{p}}\right]$ ratio as

$$
\begin{aligned}
{[\mathrm{POC}] /\left[{ }^{234} \mathrm{Thp}\right] } & =([\mathrm{POC}] /[\mathrm{SPM}]) /\left(\left[{ }^{234} \mathrm{Th}_{\mathrm{d}}\right] \times K_{\mathrm{d}}\right) \\
& =\left[f_{\mathrm{OC}}\right] /\left(\left[{ }^{234} \mathrm{Th}_{\mathrm{d}} \times K_{\mathrm{d}}\right]\right)
\end{aligned}
$$

$$
\begin{aligned}
\log [\mathrm{POC}] /\left[{ }^{234} \mathrm{Thp}\right]= & \log \left(f_{\mathrm{OC}}\right)-\log \left[{ }^{234} \mathrm{Thp}\right] \\
& -\log K_{\mathrm{d}}(o)-2.2 f_{\mathrm{PS}} \\
\approx & \text { constants }_{2}-2.2 f_{\mathrm{PS}}
\end{aligned}
$$

or

$\log \left[{ }^{234} \mathrm{Thp}\right] /[\mathrm{POC}] \approx-$ constants $+2.2 f_{\mathrm{PS}}$.

Therefore, under these circumstances, $\log \left\{\left[{ }^{234} \mathrm{Th}_{\mathrm{p}}\right] /\right.$ $[\mathrm{POC}]\}$ becomes proportional to $f_{\mathrm{PS}}$, corrected by two constants, provided that $f_{\mathrm{OC}}$ and $\left[{ }^{234} \mathrm{Th}_{\mathrm{d}}\right]$ vary only by a relatively small amount. Within a site- and time-specific study (Figs. 10 and 11), these assumptions are probably true within a factor of 2 .

For example, for the Gulf of Mexico, $f_{\mathrm{PS}}$ values range from 0.04 to 0.12 , depending on location and particle size (Hung et al., 2003a,b; Santschi et al., 2003). $f_{\mathrm{PS}}$ is small enough so that $[\mathrm{POC}] /\left[{ }^{234} \mathrm{Th}_{\mathrm{p}}\right]$ can be approximated with a linear function, which makes $[\mathrm{POC}] /\left[{ }^{234} \mathrm{Th}\right]$ proportional to $f_{\mathrm{PS}}$, as has been reported by Guo et al. (2002a), Santschi et al. (2003), and Hung et al. (2004) in the Gulf of Mexico using parameter values similar to those of Eq. (1).

\section{Sources of transparent exopolymeric particles and acidic polysaccharides}

Composition, production, and degradation of EPS and TEP, the so-called mucus- or gel-particles operationally defined as Alcian Blue stainable particles retained on filters (Alldredge et al. 1993; Verdugo et al., 2004), have been reviewed by Decho (1990), Leppard (1995, 1997), and Passow (2002). According to these authors, the cell surface of many phytoplankton and bacteria is covered by EPS, and therefore, sources of EPS and TEP in the water include exudates from both of these sources. However, their abundance and exact compositions differ with species and growth conditions.

In summary, EPS fibrils are about $100 \mathrm{~s} \mathrm{~nm}$ long, 1$2 \mathrm{~nm}$ thick, long and stiff, and form gels under the influence of $\mathrm{Ca}^{2+}$ (Santschi et al., 1998, 2005; Verdugo et al., 2004, and references therein). EPS and COM have $\sim 1$ or more $\mathrm{meq} / \mathrm{g}$ proton reactive sites (Santschi et al.,
1995), are composed of acidic sugars, but often are covalently bound to proteins and lipids (Decho, 1990; Leppard, 1995, 1997; Alvarado-Quiroz et al., 2006-this issue), and have 3 main functional groups: $\mathrm{R}_{-} \mathrm{COO}^{-}$, $\mathrm{R}-$ $\mathrm{OPO}_{3}^{2-}, \mathrm{R}_{-} \mathrm{OSO}_{3}^{-}$that can potentially bind to $\mathrm{Th}(\mathrm{IV})$ (Alvarado-Quiroz et al., 2006-this issue). About 50\% of EPS can be rapidly (hours to days) degraded by bacteria, while the remaining $50 \%$ is more refractory, and can persist for months or longer (Passow, 2002). TEP concentration in suspended matter decreases with depth.

Thus, it appears that both photosynthesizing microorganisms and heterotrophic bacteria can produce metal (e.g., Th(IV)-binding APS-containing) ligand macromolecules, while heterotrophic bacteria reduce these macromolecules in size and release enzymatically degraded fragments into the surrounding solution (Bacon, 1979; Santschi et al., 2003). This scenario is in agreement with the decreasing ${ }^{234} \mathrm{Th} / \mathrm{POC}$ ratios with increasing bacterial production (Fig. 13). Since phytoplankton and bacterial growth rates are coupled, one therefore needs to consider both groups of microorganisms when evaluating their contributions to the standing crop of ${ }^{234}$ Th-binding APS compounds. The effects of filterfeeding zooplankton and bacterivorous plankton organ-
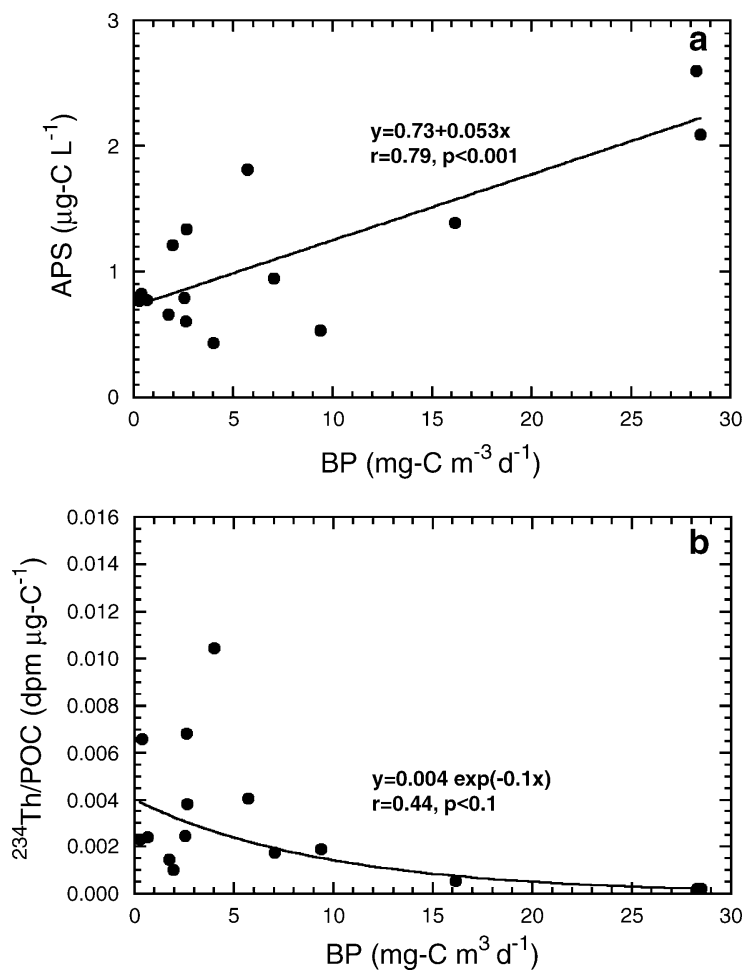

Fig. 13. (a) Relationship between bacterial production (BP) and total APS concentration and (b) ${ }^{234} \mathrm{Th} / \mathrm{POC}$ ratios in the Gulf of Mexico (Santschi et al., 2003). 
isms (Barbeau and Moffett, 2001; Kerner et al., 2003) have so far not been considered in field studies, but would also need to be further evaluated as biological amplifiers of coagulation.

\section{Recommendations for future work}

Although the above studies are intriguing, there are still many questions regarding Th speciation in natural waters that are unresolved. More experiments are needed that specifically test the role of microbially produced exopolymers (EPS, TEP) in the scavenging of Th(IV) and other radionuclides. While there is good evidence that a strongly ${ }^{234} \mathrm{Th}$-binding exopolymeric ligand is related to the concentration of large biomolecules such as EPS or TEP, and total or acid polysaccharides, it may be smaller macromolecules (e.g., $13 \mathrm{kDa}$ ) that play the most important role in Th(IV) binding. The observed relationship between $\mathrm{C}^{234}$ Th ratios and (acid) polysaccharide concentrations may be linked to the physicochemical uptake and enzymatic release of macromolecular Th-binding ligands that are associated with the surface-active fibrils, rather than straight chemical binding. This coupling of chemical and microbial processes requires further study.

A better understanding of the molecular mechanisms of Th(IV) "scavenging" are thus needed, requiring more studies that examine Th complexation to colloids and larger, more rapidly sinking particles, as well as particle aggregation. This also requires an improved measure of the relative hydrophobicity of the hydrocolloids (e.g., protein or aromatic carbon content, octanol-water partition coefficient $\log P$ ) for parameterizing "stickiness" or surfactant-like properties of the Th(IV)carrying biomolecules.

Improved insights into the molecular mechanisms of the physical, chemical and biomolecular mechanisms of Th(IV) binding to a "sticky" macromolecular ligand family of compounds also requires a paradigm shift, as the Th-ligand complex exhibits surface-activity. In particular, an improved knowledge of the relationship between the $\mathrm{POC} /\left({ }^{234} \mathrm{Th}\right)$ ratio and the ligand, polysaccharide, uronic acid, or organic carbon content (Santschi et al., 2003; Hung et al., 2003a), is needed. To this end, controlled experiments with Th(IV) tracers, using a variety of natural organic compounds extracted from cultures and/or field sites, in conjunction with inorganic matrix components of marine particles, are recommended.

It is necessary that further lab experiments focus on the ultra low Th and ligand concentrations typical of most marine environments. Lab experiments with Th(IV) tracers at environmentally relevant (low) concentration levels are difficult, as results can strongly depend on experimental (e.g., ultra-clean solutions vs. ambient impurities; the way how acid is neutralized) conditions or procedures. In addition, particle-reactive tracers such as Th(IV) are likely present as pseudo-colloids at neutral pH (Kepack, 1977, and references therein), with environmental significance only when colloidal impurities are known or controlled (Roberts and Santschi, unpublished results).

Dissolved organic matter and organic ligand speciation in natural waters is a complex issue unto itself. Combined laboratory, mesocosm and field based studies must be undertaken by multiple marine radiochemistry, organic and gel chemistry groups. These studies should attempt to characterize the speciation of the dissolved and particulate ${ }^{234} \mathrm{Th}$ pool and examine the biophysico-chemical relationships between concentrations of particulate ${ }^{234} \mathrm{Th}$ and concentrations and types of surface sites, chemical composition (e.g., types and concentrations of hydrophilic acidic polysaccharides, chemically linked to more hydrophobic proteins and/ or lipids) as well as biophysical ligand properties, and how these interactions are modified by biological activity over time. This undertaking will require a paradigm shift in our quest for a better understanding of a family of "sticky", surfactant-like macromolecular Th(IV)-binding ligands, requiring a larger investment in marine chemistry, i.e., biophysical and analytical, research.

To summarize, future work should include: (a) improvements in the analysis of acidic sugars, e.g., uronic acids and sulfated sugars; (b) determination of the extent of surface coatings on suspended particles by EPS and/or humics; (c) determination of surface properties of suspended particles vs. depth in relation to extent of U/Th disequilibrium; (d) Th binding as a function of particle composition, organic films, location in cells, and amphiphilic or amphiphatic (i.e., hydrophobic/hydrophilic) properties of EPS; (e) experimental studies that investigate the effects of grazing and plankton species; (f) investigation of the effects of coagulation and/or flocculation processes (e.g., Brownian pumping) on extent and kinetics of Th(IV) sorption; and (g) conduct appropriate sorption experiments that contrast surface ocean conditions with deep ocean conditions to mimic differences in ${ }^{234} \mathrm{Th}$ behavior in the surface ocean from that of ${ }^{230} \mathrm{Th}$ in the deep ocean.

\section{Acknowledgements}

The writing of this paper was supported in parts by NSF (OCE-0351559; OCE-0350758, and OCE 
0354757). We gratefully acknowledge constructive comments from Guest Editor, R.F. Anderson, and Katsumi Hirose and an anonymous reviewer.

\section{Appendix A}

\section{List of acronyms}

$\begin{array}{ll}\text { APS } & \begin{array}{l}\text { Acid polysaccharides, or acyl } \\ \text { polysaccharides }\end{array} \\ \text { CHO } & \text { Carbohydrate } \\ \text { COC } & \text { Colloidal organic carbon } \\ \text { COM } & \text { Colloidal organic matter } \\ \text { EPS } & \begin{array}{l}\text { Exopolymeric substances or } \\ \text { polysaccharides }\end{array} \\ & \text { Extended X-ray Absorption Fine } \\ \text { EXAFS } & \text { Structure, a synchrotron-based } \\ & \text { technique } \\ \text { EDTA } & \text { Ethylene-diamine-tetraacetic acid } \\ \text { DTPA } & \text { Diethyl-triamine-pentaacetic acid } \\ K_{\mathrm{d}} & \text { Particle-water partition coefficient } \\ K_{\mathrm{c}} & \text { Colloid-water partition coefficient } \\ \text { POC } & \text { Particulate organic carbon } \\ \text { TEP } & \text { Transparent exopolymeric particles } \\ \text { URA } & \text { Uronic acids } \\ \text { ThCC } & \text { Thorium complexation capacity }\end{array}$

\section{References}

Ahimou, F., Paquot, M., Jacques, P., Thonart, P., Rouxhet, P.G., 2001. Influence of electrical properties on the evaluation of the surface hydrophobicity of Bacillus subtilis. J. Microbiol. Methods 45, $119-126$.

Ahmad, R., Arakawa, H., Tajmir-Riahi, H., 2003. A comparative study of DNA complexation with $\mathrm{Mg}(\mathrm{II})$ and $\mathrm{Ca}(\mathrm{II})$ in aqueous solution: major and minor grooves bindings. Biophys. J. 84, $2460-2466$

Alldredge, A.L., Gotschalk, C., 1988. In-situ settling behavior of marine snow. Limnol. Oceanogr. 33, 339-351.

Alldredge, A.L., Jackson, G.A., 1995. Aggregation in marine systems. Deep-Sea Res. 42, 1-8.

Alldredge, A.L., Passow, U., Logan, B.E., 1993. The abundance and significance of a class of large, transparent organic particles in the ocean. Deep-Sea Res., I 40, 1131-1140.

Aluwihare, L., Repeta, D., Chen, R., 2002. Chemical composition and cycling of dissolved organic matter in the Mid-Atlantic Bight. Deep Sea Res., II 49, 4421-4437.

Alvarado-Quiroz, N., 2004. Characterization of marine exopolymeric substances (EPS) responsible for binding of thorium(IV) isotopes. $\mathrm{PhD}$ dissertation, Texas A\&M University, College Station, TX.

Alvarado-Quiroz, N., Hung, C.-C., Santschi, P.H., 2006. Binding of thorium(IV) to carboxylic acid, phosphate, and sulfate functional groups from marine exopolymeric substances (EPS). Mar. Chem. 100, 337-353. doi:10.1016/j.marchem.2005.10.023 (this issue).
Amon, R.M.W., Benner, R., 1994. Rapid cycling of high-molecular weight dissolved organic matter in the ocean. Nature 369, $549-552$.

Anderson, R.F., Bacon, M.P., Brewer, P.G., 1982. Elevated concentrations of actinides in Mono Lake. Science 216, 514-516.

Anderson, R.F., Bacon, M.P., Brewer, P.G., 1983. Removal of ${ }^{230} \mathrm{Th}$ and ${ }^{231} \mathrm{~Pa}$ at ocean margins. Earth Planet. Sci. Lett. 66, 73-90.

Anderson, R.F., Fleisher, M.Q., Biscaye, P.E., et al., 1994. Anomalous boundary scavenging in the Middle Atlantic Bight-evidence from Th-230, Pa-231, Be-10, and Pb-210. Deep-Sea Res., II 41, 537-561.

Artinger, R., Buckau, G., Zeh, P., Geraedts, K., Vancluysen, J., Maes, A., Kim, J.I., 2003. Humic colloid mediated transport of tetravalent actinides and technetium. Radiochim. Acta 91, 743-750.

Avnimelech, Y., Troeger, B., 1982. Mutual flocculation on algae and clay: evidence and implications. Science 216, 63-65.

Bacon, J.S.D., 1979. Factors limiting the action of polysaccharide degrading enzymes. In: Berkeley, R.C.W., et al., (Eds.), Microbial Polysaccharides and Polysaccharases. Academic Press, New York, pp. 269-284.

Bacon, M.P., Anderson, R.F., 1982. Distribution of thorium isotopes between dissolved and particulate forms in the deep sea. J. Geophys. Res. 87, 2045-2056.

Bacon, M.P., Rutgers v. d. Loeff, M.M., 1989. Removal of Thorium234 by scavenging in the bottom nepheloid layer of the ocean. Earth Planet. Sci. Lett. 92, 157-164.

Bacon, M.P., Belastock, R.A., Tecotzky, M., Turekian, K.K., Spencer, D.W., 1988. Lead-210 and polonium-210 in ocean water profiles of the continental shelf and slope south of New England. Cont. Shelf Res. 8, 841-853.

Bacon, M.P., Cochran, J.K., Hirschberg, D., Hammar, T.R., Fleer, A.P., 1996. Export flux of carbon at the equator during the EqPac time-series cruises estimated from ${ }^{234} \mathrm{Th}$ measurements. Deep-Sea Research, II 43, 1133-1154.

Barbeau, K., Moffett, J.W., 2001. Remineralization and recycling of iron, thorium and organic carbon by heterotrophic marine protozoa. Aquat. Microb. Ecol. 24, 69-81.

Baskaran, M., Santschi, P.H., Benoit, G., Honeyman, B.D., 1992. Scavenging of thorium isotopes by colloids in seawater of the Gulf of Mexico. Geochim. Cosmochim. Acta 56, $3375-3388$.

Baskaran, M., Santschi, P.H., Guo, L., Bianchi, T.S., Lambert, C., 1996. ${ }^{234} \mathrm{Th}:{ }^{238} \mathrm{U}$ disequilibria in the Gulf of Mexico: importance of organic matter and particle concentration. Cont. Shelf Res. 16, $353-380$

Baskaran, M., Swarzenski, P.W., Porcelli, D., 2003. Role of colloidal material in the removal of ${ }^{234} \mathrm{Th}$ in the Canada Basin of the Arctic Ocean. Deep-Sea Res. 50, 1353-1373.

Benitez-Nelson, C., Buesseler, K.O., Karl, D.M., Andrews, J., 2001. A time-series study of particulate matter export in the North Pacific Subtropical Gyre based on ${ }^{234} \mathrm{Th}:{ }^{238} \mathrm{U}$ disequilibrium. Deep-Sea Res., I 48, 2595-2611.

Benner, R., 2002. Chemical composition and reactivity. In: Hansell, D.A., Carlson, C.A. (Eds.), Biogeochemistry of Marine Dissolved Organic Matter. Academic Press, New York, pp. 59-90.

Bruno, J., 1990. The influence of dissolved carbon dioxide on trace metal speciation in seawater. Mar. Chem. 30, 231-240.

Buesseler, K.O., 1998. The de-coupling of production and particle export in the surface ocean. Glob. Biogeochem. Cycles 12, 297-310.

Buessele, K.O., Benitez-Nelson, C.R., Moran, S.B., Burd, A., Charette, M., Cochran, J.K., Coppola, L., Fisher, N.S., Fowler, S.W., 
Gardner, W.D., Guo, L.D., Gustafsson, O., Lamborg, C., Masque, P., Miquel, J.C., Passow, U., Santschi, P.H., Savoye, N., Stewart, G., Trull, T., 2006. An assessment of particulate organic carbon to thorium-234 ratios in the ocean and their impact on the application of ${ }^{234} \mathrm{Th}$ as a POC flux proxy. Mar. Chem. 100, 213-233. doi:10.1016/j.marchem.2005.10.013 (this issue).

Buffle, J., 1990. Complexation Reactions in Aquatic Systems: An Analytical Approach. Ellis Horwood, New York

Burd, A.B., Moran, S.B., Jackson, G.A., 2000. A coupled adsorptionaggregation model of the $\mathrm{POC} /{ }^{234} \mathrm{Th}$ ratio of marine particles. Deep-Sea Res., I 47, 103-120.

Chase, Z., Anderson, R.F., Fleisher, M.Q., Kubik, P.W., 2002. The influence of particle composition and particle flux on scavenging of Th, Pa and Be in the ocean. Earth Planet. Sci. Lett. 204, 215-229.

Choppin, G.R., Nash, K.L., 1981. Dissociation kinetics of thorium and humic acid. J. Inorg. Nucl. Chem. 43, 357-359.

Choppin, G.R., Stout, B.E., 1989. Actinide behavior in natural waters. Sci. Total Environ. 83, 203-216.

Choppin, G.R., Wong, P.J., 1998. The chemistry of actinide behavior in marine systems. Aquat. Geochem. 4, 77-101.

Clegg, S.L., Whitfield, M., 1990. A generalized model for the scavenging of trace metals in the open ocean: I. Particle cycling. DeepSea Res. 37, 809-832.

Clegg, S.L., Whitfield, M., 1991. A generalized model for the scavenging of trace metals in the open ocean: II. Thorium scavenging. Deep-Sea Res. 38, 91-120.

Cochran, J.K., 1992. The oceanic chemistry of the uranium and thorium-series nuclides. In: Ivanovich, M., Harmon, R. (Eds.), Uranium Series Disequilibrium-Application to Environmental Problems: Applications to Earth, Marine, and Environmental Sciences, 2nd edition. Oxford University Press, pp. 334-395.

Comans, R.N.J., Haller, M., Depreter, P., 1991. Sorption of cesium on illite-nonequilibrium behavior and reversibility. Geochim. Cosmochim. Acta 55, 433-440.

Cowen, J., Bruland, K., 1985. Metal deposits associated with bacteria-implications for Fe and Mn marine biogeochemistry. Deep Sea Res. 32, 253-272.

Dai, M.H., Benitez-Nelson, C.R., 2001. Colloidal organic carbon and ${ }^{234} \mathrm{Th}$ in the Gulf of Maine. Mar. Chem. 74, 181-196.

Decho, A.W., 1990. Microbial exopolymer secretions in the ocean environments their role(s) in food webs and marine processes. Oceanogr. Mar. Biol. Annu. Rev. 28, 73-153.

Deng, H., Bloomfield, V.A., Benevides, J.M., Thomas Jr., G.J., 2000. Structural basis of polyamine-DNA recognition: spermidine and spermine interactions with genomic B-dans of different GC content probed by Raman spectroscopy. Nucleic Acids Res. 28, 3379-3385.

Dickinson, E., 2003. Hydrocolloids at interfaces and the influence on the properties of dispersed systems. Food Hydrocoll. 17, $25-39$.

Doucet, F.J., Lead, J.R., Santschi, P.H., 2006. Role of colloids in mediating trace element fate and behaviour in aquatic systems. In: Lead, J.R., Wilkinson, K.J. (Eds.), Environmental Colloids: Behaviour, Separation and Characterization. International Union of Pure and Applied Chemistry (Environmental Analytical and Physical Chemistry Series).

Ducklow, H.W., Steinberg, D.K., Buesseler, K.O., 2001. Upper ocean carbon export and the biological pump. Oceanography 14 (4), 50-58 (JGOFS, Special issue).

Dunne, J.P., Murray, J.W., Young, J., Balistrieri, L.S., Bishop, J., 1997. ${ }^{234} \mathrm{Th}$ and particle cycling in the central equatorial Pacific. Deep-Sea Res., II 44, 2049-2084.
Edwards, R.L., Chen, J.H., Ku, T.-L., Wasserburg, G.J., 1987. Precise timing of the last interglacial period from mass spectrometric determination of thorium-230 in corals. Science 236, 1547-1553.

Everett, D.H., Whitton, W.I., 1952. A general approach to hysteresis: I. Trans. Faraday Soc. 48, 749-757.

Fanghänel, T., Neck, V., 2002. Aquatic chemistry and solubility phenomena of actinide oxides/hydroxides. Pure Appl. Chem. $72,1895-1907$

Fisher, N.S., Teyssie, J.-L., Krishnaswami, S., Baskaran, M., 1987. Accumulation of $\mathrm{Th}, \mathrm{Pb}, \mathrm{U}$, and $\mathrm{Ra}$ in marine phytoplankton and its geochemical significance. Limnol. Oceanogr. 32, 131-142.

Geibert, W., Usbeck, R., 2004. Adsorption of thorium and protactinium onto different particle types: experimental findings. Geochim. Cosmochim. Acta 68, 1489-1501.

Greenamoyer, J.M., Moran, S.B., 1997. Investigation of $\mathrm{Cd}, \mathrm{Cu}, \mathrm{Ni}$ and ${ }^{234} \mathrm{Th}$ in the colloidal size range in the Gulf of Maine. Mar. Chem. 57, 217-226.

Guo, L., Santschi, P.H., 1997. Composition and cycling of colloids in marine environments. Rev. Geophys. 35, 17-40.

Guo, L., Santschi, P.H., 2005. Ultrafiltration technique and its application to sampling and characterization of aquatic colloids. In: Lead, J.R., Wilkinson, K.J. (Eds.), Environmental Colloids: Behaviour, Separation and Characterization, Environmental Analytical and Physical Chemistry Series. International Union of Pure and Applied Chemistry. (in revision).

Guo, L., Santschi, P.H., Baskaran, M., Zindler, A., 1995. Distribution of dissolved and particulate ${ }^{230} \mathrm{Th}$ and ${ }^{232} \mathrm{Th}$ in seawater from the Gulf of Mexico and off Cape Hatteras, as measured by SIMS Earth Planet. Sci. Lett. 133, 117-128.

Guo, L., Santschi, P.H., Cifuentes, L.A., Trumbore, S., Southon, J., 1996. Cycling of high molecular weight dissolved organic matter in the Middle Atlantic Bight as revealed by carbon isotopic $\left({ }^{13} \mathrm{C}\right.$ and ${ }^{14} \mathrm{C}$ ) signatures. Limnol. Oceanogr. 41, 1242-1252.

Guo, L., Santschi, P.H., Baskaran, M., 1997. Interaction of thorium isotopes with colloidal organic matter in oceanic environments. Colloids Surf., A 120, 255-272.

Guo, L., Hung, C.C., Santschi, P.H., Walsh, I.D., 2002. ${ }^{234}$ Th scavenging and its relationship to acid polysaccharide abundance in the Gulf of Mexico. Mar. Chem. 78, 103-119.

Guo, L., Chen, M., Gueguen, C., 2002. Control of Pa/Th ratio by particulate chemical composition. Geophys. Res. Lett. 29, 1960

Gustafsson, Ö., Gschwend, P.M., Buesseler, K.O., 1997. Using ${ }^{234}$ Th disequilibria to estimate the vertical removal rates of polycyclic aromatic hydrocarbons from the surface ocean. Mar. Chem. 57, $11-23$.

Gustafsson, Ö., Gschwend, P.M., Buesseler, K.O., 1997. Settling removal rates of PCBs into the northwestern Atlantic derived from ${ }^{238} \mathrm{U}-{ }^{234} \mathrm{Th}$ disequilibria. Environ. Sci. Technol. 31, 3544-3550.

Hirose, K., 1996. Determination of a strong organic ligand dissolved in seawater: thorium-complexing capacity of oceanic dissolved organic matter. J. Radioanal. Nucl. Chem., Art. 204, 193-204.

Hirose, K., 2004. Chemical speciation of thorium in marine biogenic particulate matter. Sci. World J. 4, 67-76.

Hirose, K., Tanoue, E., 1994. Thorium-particulate matter interaction. Thorium complexing capacity of oceanic particulate matter: theory. Geochim. Cosmochim. Acta 58, 1-7.

Hirose, K., Tanoue, E., 1998. The vertical distribution of the strong ligand in particulate organic matter in the North Pacific. Mar. Chem. 59, 235-252.

Hirose, K., Tanoue, E., 2001. Strong ligands for thorium complexation in marine bacteria. Mar. Environ. Res. 51, 95-112. 
Honeyman, B.D., Santschi, P.H., 1989. Brownian-pumping model for oceanic trace metal scavenging: evidence from Th isotopes. J. Mar. Res. 47, 951-992.

Honeyman, B.D., Balistrieri, L.S., Murray, J.W., 1988. Oceanic trace metal scavenging: the importance of particle concentration. DeepSea Res. 35, 227-246.

Huh, C.A., Moore, W.S., Kadko, D.C., 1989. Oceanic ${ }^{232}$ Th: a reconnaissance and implications of global distribution from manganese nodules. Geochim. Cosmochim. Acta 53, 1357-1366.

Hung, C.-C., Guo, L., Santschi, P.H., Alvarado-Quiroz, N.J., Haye, J., 2003. Distributions of carbohydrate species in the Gulf of Mexico. Mar. Chem. 81, 119-135.

Hung, C.-C., Guo, L., Schultz, G., Pinckney, J.L., Santschi, P.H., 2003. Production and fluxes of carbohydrate species in the Gulf of Mexico. Glob. Biogeochem. Cycles 17 (2). doi:10.1029/ 2002GB001988 (Art. No. 1055).

Hung, C.-C., Guo, L.D., Roberts, K.A., Santschi, P.H., 2004. Upper ocean carbon flux determined by size-fractionated ${ }^{234} \mathrm{Th}$ data and sediment traps in the Gulf of Mexico. Geochem. J. 38 (6), 601-611.

Hunter, K.A., Liss, P.S., 1979. The surface charge of suspended particles in estuarine and coastal waters. Nature 282, 823-825.

Hunter, K.A., Hawke, D.J., Choo, L.K., 1988. Equilibrium adsorption of thorium by metal oxides in marine electrolytes. Geochim. Cosmochim. Acta 52, 627-636.

Kepack, F., 1977. Behavior of carrier-free radionuclides. In: Evans, E.A., Muramatsu (Eds.), Radiotracer Techniques and Applications, vol. 1. Marcel Dekker Inc., New York, pp. 339-374 (Chap. 8).

Kepkay, P.E., 1994. Particle aggregation and biological reactivity of colloids. Mar. Ecol. Prog. Ser. 109, 293-304.

Kerner, M., Hohenberg, H., Ertl, S., Reckermann, M., Spitzy, A., 2003. Self-organization of dissolved organic matter to micelle-like microparticles in river water. Nature 422, 150-154.

Kohn, R., 1972. Ion binding on polyuronides-alginate and pectin. Pure Appl. Chem. 42, 371-397.

La Flamme, B.D., Murray, J.W., 1987. Solid/solution interaction: the effect of carbonate alkalinity on adsorbed thorium. Geochim. Cosmochim. Acta 51, 243-250.

Langmuir, D., Herman, J.S., 1980. The mobility of thorium in natural waters at low temperatures. Geochim. Cosmochim. Acta 44, $1753-1766$.

Lead, J., Hamilton-Taylor, J., Davison, W., Harper, M., 1999. Trace metal sorption by natural particles and coarse colloids. Geochim. Cosmochim. Acta 63, 1661-1670.

Lee, T., Barg, E., Lal, D., Azam, F., 1993. Bacterial scavenging of Th234 in surface ocean waters. Mar. Ecol. Prog. Ser. 96, 109-116.

Leppard, G., 1995. The characterization of algal and microbial mucilages and their aggregates in aquatic ecosystems. Sci. Total Environ. $165,103-131$.

Leppard, G., 1997. Colloidal organic fibrils of acid polysaccharides in surface water: electron-optical characteristics, activities and chemical estimates of abundance. Colloids Surf., A Physicochem. Eng. Asp. 120, 1-15.

Litton, G.M., Olson, T.M., 1993. Colloid deposition rates on silica bed media and artifacts related to collector surface preparation methods. Environ. Sci. Technol. 27, 185-193.

Luo, S.D., Ku, T.L., 2004. On the importance of opal, carbonate, and lithogenic clays in scavenging and fractionating Th-230, Pa-231 and Be-10 in the ocean. Earth Planet. Sci. Lett. 220, 201-211.

Marchal, O., Francois, R., Stocker, T.F., Joos, F., 2000. Ocean thermohaline circulation and sedimentary ${ }^{231} \mathrm{~Pa} /{ }^{230} \mathrm{Th}$ ratio. Paleoceanography $15,625-641$.
Martell, A.E., Smith, R.M., 1990. Critical Stability Constants. Plenum Press, NY.

Mayer, L.M., 1994. Surface area control of organic carbon accumulation in continental shelf sediments. Geochim. Cosmochim. Acta 58, $1271-1284$.

Mayer, L.M., 1999. Extent of coverage of mineral surfaces by organic matter in marine sediments. Geochim. Cosmochim. Acta 63, $207-215$.

Moe, S., Draget, K., Skjåk-Bræk, G., Smidrød, O., 1995. Alginates. In: Stephen, A. (Ed.), Food Polysaccharides and Their Application. Marcel Dekker, Inc., pp. 245-286.

Moore, W.S., 1981. The thorium content of ocean water. Earth Planet. Sci. Lett. 53, 419-426.

Moran, S.B., Buesseler, K.O., 1992. Short residence time of colloids in the upper ocean estimated from ${ }^{238} \mathrm{U} /{ }^{234} \mathrm{Th}$ disequilibria. Nature $359,221-223$.

Moran, S.B., Buesseler, K.O., 1993. Size-fractionated ${ }^{234} \mathrm{Th}$ in continental shelf waters off New England: implications for the role of colloids in oceanic trace metal scavenging. J. Mar. Res. 51, $893-922$.

Moran, S.B., Shen, C.-C., Edmonds, H.N., Weinstein, S.E., Smith, J.N., Edwards, R.L., 2002. Dissolved and particulate Pa-231 and Th-230 in the Atlantic Ocean: constraints on intermediate/deep water age, boundary scavenging, and Pa-231/Th-230 fractionation. Earth Planet. Sci. Lett. 203, 999-1014.

Moulin, V., Moulin, C., 2001. Radionuclide speciation in the environment: a review. Radiochim. Acta 89, 773-778.

Moulin, V., Amekraz, B., Barre, N., Planque, G., Mercier, F., Reiller, P., Moulin, C., 2004. The role of humic substances in trace element mobility in natural environments and applications to radionuclides. In: Ghabbour, E., Davies, G. (Eds.), Humic Substances. Nature's Most Versatile Materials. Taylor and Francis, Inc., New York.

Muller, F.L.L., 1998. Colloid/solution partitioning of metal-selective organic ligands, and its relevance to $\mathrm{Cu}, \mathrm{Pb}$ and $\mathrm{Cd}$ cycling in the Firth of Clyde. Estuar. Coast. Shelf Sci. 46, 419-437.

Muller, F., 1999. Evaluation of the effects of natural dissolved and colloidal organic ligands on the electrochemical lability of $\mathrm{Cu}, \mathrm{Pb}$, and $\mathrm{Cd}$ in the Arran Deep, Scotland. Mar. Chem. 67, 43-60.

Murphy, R.J., Lenhart, J.J., Honeyman, B.D., 1999. The sorption of thorium (IV) and uranium (VI) to hematite in the presence of natural organic matter. Colloids Surf., A Physicochem. Eng. Asp. $157,47-62$.

Murray, J.W., Downs, J., Strom, S., Wei, C.-L., Jannasch, H., 1989. Nutrient assimilation, export production and ${ }^{234}$ Th scavenging in the Eastern Equatorial Pacific. Deep-Sea Res. 36, 1471-1489.

Murray, J.W., Paul, B., Dunne, J.P., Chapin, T., 2005. Th-234, Pb210, $\mathrm{Po}-210$ and stable $\mathrm{Pb}$ in the central equatorial Pacific: tracers for particle cycling. Deep-Sea Res. I 52, 2109-2139.

Nash, K.L., Choppin, G.R., 1980. Interaction of humic and fulvic acids with Th(IV). J. Inorg. Nucl. Chem. 42, 1045-1050.

Neck, V., Altmaier, M., Müller, R., Bauer, A., Fanghänel, Th., Kim, J.I., 2003. Solubility of crystalline thorium dioxide. Radiochim. Acta 91, 253-262.

Niven, S.E.H., Moore, R.M., 1993. Thorium sorption in seawater suspensions of aluminum oxide particles. Geochim. Cosmochim. Acta 57 (10), 2169-2179.

Niven, S.E.H., Kepkay, P.E., Boraie, A., 1995. Colloidal organic carbon and colloidal ${ }^{234} \mathrm{Th}$ dynamics during a coastal phytoplankton bloom. Deep-Sea Res., II 42, 257-273.

Nyffeler, U.P., Li, Y.-H., Santschi, P.H., 1984. A kinetic approach to describe trace element distribution between particles and solution 
in natural aquatic systems. Geochim. Cosmochim. Acta 48, $1513-1522$

Östhols, E., 1995. Thorium sorption on amorphous silica. Geochim. Cosmochim. Acta 59, 1235-1249.

Östhols, E., Bruno, J., Grenthe, I., 1994. On the influence of carbonate on mineral dissolution: III. The solubility of microcrystalline $\mathrm{ThO}_{2}$ in $\mathrm{CO}_{2}-\mathrm{H}_{2} \mathrm{O}$ media. Geochim. Cosmochim. Acta 58, 613-623.

Östhols, E., Manceau, A., Farges, F., Charlet, L., 1997. Adsorption of thorium on amorphous silica: an EXAFS study. J. Colloid Interface Sci. 194, 10-21.

Passow, U., 2002. Transparent exopolymer particles (TEP) in aquatic environments. Prog. Oceanogr. 55, 287-333.

Passow, U., Dunne, J., Murray, J.W., Balistrieri, L., Alldredge, A.L., 2006. Organic carbon to ${ }^{234} \mathrm{Th}$ ratios of marine organic matter. Mar. Chem. 100, 323-336. doi:10.1016/j.marchem.2005.10.020 (this issue).

Perdue, E.M., Reuter, J.H., Goal, M., 1980. The operational nature of acidic functional group analyses and its impact on mathematical descriptions of acid-base equilibria in humic substances. Geochim. Cosmochim. Acta 44, 1841-1851.

Quigley, M., Honeyman, B.D., Santschi, P.H., 1996. Thorium sorption in the marine environment: equilibrium partitioning at the hematite/water interface, sorption/desorption kinetics and particle tracing. Aquat. Geochem. 1, 277-301.

Quigley, M.S., Santschi, P.H., Guo, L., Honeyman, B.D., 2001. Sorption irreversibility and coagulation behavior of ${ }^{234} \mathrm{Th}$ with surface-active marine organic matter. Mar. Chem. 76, 27-45.

Quigley, M.S., Santschi, P.H., Hung, C.-C., Guo, L., Honeyman, B.D., 2002. Importance of polysaccharides for ${ }^{234} \mathrm{Th}$ complexation to marine organic matter. Limnol. Oceanogr. 47, 367-377.

Rees, D.A., 1972. Polysaccharide gels, a molecular view. Chem. Ind. Lond. Soc. Chem. Ind. 19, 630-636.

Reiller, P., Moulin, V., Casanova, F., Dautel, C., 2003. On the study of Th(IV)-humic acid interactions by competition sorption studies with silica and determination of global interaction constants. Radiochim. Acta 91, 513-524.

Ron, E.Z., Rosenberg, E., 2001. Natural roles of biosurfactants. Environ. Microbiol. 3, 229-236.

Rutgers van der Loeff, M.M., Buesseler, K.O., Bathmann, U., Hense, I., Andrews, J., 2002. Comparison of carbon and opal export rates between summer and spring bloom periods in the region of the Antarctic Polar Front, SE Atlantic. Deep-Sea Res., II 49 (18), 3849-3870.

Salomons, W., 1980. Adsorption processes and hydrodynamic conditions in estuaries. Environ. Sci. Technol. Lett. 1, 356-365.

Santschi, P.H., Guo, L., Baskaran, M., Trumbore, S., Southon, J., Bianchi, T.S., Honeyman, B., Cifuentes, L., 1995. Isotopic evidence for contemporary origin of high-molecular weight organic matter in oceanic environments. Geochim. Cosmochim. Acta 59, $625-631$.

Santschi, P.H., Balnois, E., Wilkinson, E., Buffle, J., Guo, L., 1998. Fibrillar polysaccharides in marine macromolecular organic matter as imaged by atomic force microscopy and transmission electron microscopy. Limnol. Oceanogr. 43, 896-908.

Santschi, P.H., Guo, L., Walsh, I.D., Quigley, M.S., Baskaran, M., 1999. Boundary exchange and scavenging of radionuclides in continental margin waters of the Middle Atlantic Bight. Implications for organic carbon fluxes. Cont. Shelf Res. 19, 609-636.

Santschi, P.H., Hung, C.-C., Guo, L., Pinckney, J., Schultz, G., Alvarado-Quiroz, N., Walsh, I., 2003. Control of acid polysaccharide production, and ${ }^{234} \mathrm{Th}$ and POC export fluxes by marine organisms. Geophys. Res. Lett. 30 (2). doi:10.1029/2002GL016046 (Art. No. 1044).

Santschi, P.H., Burd, A.B., Gaillard, J.-F., Lazarides, A.A., 2005. Transport of materials and chemicals by nano-scale colloids and micro to macro-scale flocs in marine, freshwater and engineered systems. In: Droppo, I.G., Leppard, G.G., Liss, S.N., Milligan, T.G. (Eds.), Flocculation in Natural and Engineered Environmental Systems. CRC Press, Boca Raton, FL, pp. 191-210 (chap. 9).

Savoye, N., Benitez-Nelson, C., Burd, A.B., Cochran, J.K., Charette, M., Buesseler, K.O., Jackson, G., Roy-Barman, M., Schmidt, S., Elskens, M., 2006. ${ }^{234}$ Th sorption and export models in the water column: a review. Mar. Chem. 100, 234-249. doi:10.1016/j. marchem.2005.10.014 (this issue).

Simpson, H.J., Trier, R.M., Toggweiler, J.R., et al., 1982. Radionuclides in Mono Lake, California. Science 216 (4545), 512-514.

Smith, R.M., Martell, A.E., 1989. Critical Stability Constants (Vol. 6, 2nd supplement). Plenum Press, New York.

Smoak, J.M., Moore, W.S., Thunell, R.C., 2000. Influence of boundary scavenging and sediment focusing on Th-234, Th-228 and Pb210 fluxes in the Santa Barbara Basin. Estuar. Coast. Shelf Sci. $51,373-384$

Stenström, T.A., 1989. Bacterial hydrophobicity, an overall parameter for the measurement of adhesion potential to soil particles. Appl. Environ. Microbiol. 55, 142-147.

Stumm, W., Morgan, J.J., 1996. J. Aquatic Chemistry: Chemical Equilibria and Rates in Natural Waters, 3rd edition. Wiley and Sons, New York.

Town, R.M., Filella, M., 2000. Dispelling the myths: is the existence of L1 and L2 ligands necessary to explain metal ion speciation in natural waters? Limnol. Oceanogr. 45, 1341-1357.

Verdugo, P., Alldredge, A.L., Azam, F., Kirchman, D.L., Passow, U., Santschi, P.H., 2004. The oceanic gel phase: a bridge in the DOM-POM continuum. Mar. Chem. 92, 67-85.

Weinstein, S.E., Moran, S.B., 2005. Vertical flux of particulate Al, Fe, $\mathrm{Pb}$, and $\mathrm{Ba}$ from the upper ocean estimated from Th-234/U-238 disequilibria. Deep-Sea Res. I 52, 1477-1488.

Wells, M.L., Goldberg, E., 1992. Occurrence of small colloids in seawater. Nature 353, 342-344.

Wilkinson, K.J., Balnois, E., Leppard, G.G., Buffle, J., 1999. Characteristic features of the major components of freshwater colloidal organic matter revealed by transmission electron and atomic force microscopy. Colloids Surf., A Physicochem. Eng. Asp. $155,287-310$.

Yu, E.-F., Francois, R., Bacon, M.P., 1996. Similar rates of modern and last-glacial ocean thermohaline circulation inferred from radiochemical data. Nature 379, 689-694.

Zhang, L., Chen, M., Yang, W.F., Xing, N., Li, Y.P., Qiu, Y.S., Huang, Y.P., 2005. Size fractionated thorium isotopes $\left({ }^{228} \mathrm{Th},{ }^{230} \mathrm{Th}\right.$, ${ }^{232} \mathrm{Th}$ ) in surface waters in the Jiulong River estuary, China. J. Environ. Radioact. 78, 199-216. 